\title{
Uncertainty and Risk Analysis of Pakistan's Housing Market: Fan Chart Approach
}

\author{
Rafiq Ahmed * $\quad$ Syed Tehseen Jawaid ${ }^{\dagger} \quad$ Samina Khalil ${ }^{\ddagger}$
}

\begin{abstract}
Economic forecasting is necessary to revise and check the effectiveness of the existing policies. This serves as a pioneer study to forecast house prices (HP), foreign direct investment (FDI), and worker's remittances (WR) using the time series data ranging from 1973 to 2018 on the economy of Pakistan. The analysis is performed on a yearly, quarterly, and monthly basis to present the detailed synthesis. Fan chart methodology is used to forecast growth rates of house price, foreign direct investment, and worker's remittances for ten years 2019-2028. The results of the analysis support the proposition that there is uncertainty associated with house prices. To get beneficial results, the economic managers should carefully design a housing policy so that upside and downside risks are minimized.
\end{abstract}

Keywords: Fan Chart, House prices, foreign direct investment, worker's remittances, forecasting, Pakistan.

\section{Introduction}

Macroeconomic forecasting plays a crucial role in the decision-making process of any economy by guiding policymakers to pay special attention to volatile components, particularly planning for the housing sector. Regular and timely monitoring of the previous forecasts improves its accuracy which serves public authorities efficiently. The housing sector serves almost the entire economy in this instance, its close monitoring is necessary to avoid any price volatility which can hamper other macroeconomic aggregates. The appreciation of housing prices is a global phenomenon but the world has witnessed the global subprime crisis which disturbed the entire world economic indicators. This is due to imprudent lending, overlooked mortgage procedures by banks and non-bank financial institutions, or the lack of proper planning and forecasting of the future trend. In addition to this Asian financial crisis broke in most Asian countries which also put downward pressure on the global economy. Thailand is the best example where the crisis began and the importance of the real estate sector was almost overlooked (Renaud, Zhang, \& Koeberle, 2001). The housing sector has established its prominent position in an economy that cannot be overlooked and

\footnotetext{
${ }^{*}$ PhD Scholar, Applied Economics Research Centre, University of Karachi, Pakistan.

Email: rafiqsoomro@gmail.com

${ }^{\dagger}$ Assistant Professor/ Research Economist, Applied Economics Research Centre, University of Karachi,

Pakistan. Email: stjawaid@hotmail.com

$\ddagger$ Professor, Applied Economics Research Centre, University of Karachi, Pakistan.

Email: samina.khalil@gmail.com
} 
the debate among researchers and analysts is increasing for the case of the Hong Kong economy (Fung \& Forrest, 2002). It is concluded that more open Asian economies suffer more during the crisis period (Chiu, 2006).

Housing is an important sector in the economic performance of a developing country because it serves the residential needs of the individuals in an economy. The gross residential construction is counted in the national accounts of any country, also it can facilitate the workers to have safe cover for their families. Such facilities increase the productivity of households. Pakistan is also a developing economy located in the South Asian region, with a GDP per capita income of US $\$ 1197.84^{1}$; it is desirous of everybody to have a house to live in but with such a low earning level it is difficult for people to acquire a housing unit. The rapid growth in population and rural to urban migration have put enormous pressure on the housing sector, there is also a problem of housing finance, the role financial sector is minimal hence people rely on informal sources for housing finance. Rapidly rising housing prices and the supply-demand gap in the housing market created instability and caused a disturbance in the overall economic management. This lack of finances for the housing call for the contribution of the foreign capital inflow, people mostly using worker's remittances to finance housing decisions in the country. In addition to this, the impact of foreign direct investment in the housing sector is increasing with time. In this instance, it has become necessary to analyze the behavior of the housing market and its future trend analysis.

Pakistan like most other developing countries is facing a deficit of affordable housing for households whose earning capacity is low, this is especially due to uncontrolled urbanization. The emergence of informal settlements and slums are formed due to the inability of residents to buy an area of land for the construction of houses and lack of public policy for planning the urban settlements. The country's informal settlements constitute about 27 million out of the 207 million total population of the country (Malik, Roosli, \& Tariq, 2020). There is a dire need for research in this area to highlight the important points of actions for the public authority to frame a housing policy to cater to the burning problem of housing in the country.

The objective of this current study is to forecast the growth rate of housing prices which is inevitable for economic planning, apart from income, interest rate, and other macroeconomic factors, housing prices are greatly affected by income sources from abroad. The impact of foreign capital inflow and worker's remittances is the motivation of this study. The paper is designed to cater to the objective in this manner, the following section cover related literature on the subject, a fan chart is presented afterward and the paper presents concluding remarks at the end.

\section{Literature Review}

Globally, the housing market has gained such importance that it plays a vital role in the macroeconomic fluctuations, it has become an important economic indicator for an economy. When prices of housing increase it caused overheating the economic performance, and declining housing prices indicate a slowdown that is also not desirable and such a

\footnotetext{
${ }^{1}$ Gross Domestic Product, WDI World Bank 2018
} 
regular up and down in the housing prices is not a healthy economic sign (Leamer, 2007). It is of vital interest to the public at large to learn the ebb and flow of the housing market more efficiently. The dire need of the time is to forecast such movements in the housing prices to design an efficient housing policy.

There is a lot of factors that affect housing prices such as gross domestic product GDP, rate of inflation, money supply, interest rate, and population. Income is the most important factor which affects housing prices, many studies have used income as a potential driver of housing prices (Annett, 2005; McCarthy \& Peach, 2004; Meen, 2002). Usually, houses are costly to build or purchase so that one cannot afford to buy from their current income sources albeit everyone wants a house to live in and provide shelter to their offspring too. Houses are financed by banks and non-bank financial institutions around the world so the role of the financial sector is important in housing finances. Given the large capital investment in housing, it is financed through mortgages that in turn are largely governed by interest rates (Himmelberg, Mayer, \& Sinai, 2005; Iacoviello, 2002).

The changes in housing prices have been defined by macroeconomic factors, but the main task is to forecast the future trend in the housing market. There are various modeling techniques to forecast house prices, some of them include the error correction model (Malpezzi, 1999), and Kalman filter (Clapp \& Giaccotto, 2002). It incorporated generalized autoregressive conditional heteroscedasticity $(\mathrm{GARCH})$ and autoregressive integrated moving average (ARIMA) (Crawford \& Fratantoni, 2003); along with these they also used regime-switching models to forecast housing prices. Both the models perform good results, ARIMA is good for out of sample phenomena whereas the regime-switching model is good for the in-sample forecast. Similarly, Monte Carlo simulation is by Giaccotto and Clapp (1992) and they used Bayesian and non-Bayesian methods for the analysis, a similar phenomenon is also found out by Geltner, MacGregor, and Schwann (2003) for the United Kingdom hereafter named the UK.

In another study (Brown, Song, \& McGillivray, 1997) showed that the forecasting results of the time-varying coefficient model are better than the vector autoregressive model and error correction mechanism for the economy of the UK. However, Guirguis, Giannikos, and Anderson (2005) used the rolling GARCH and time-varying parameter models for the economy of the United States hereafter named as the UK, to find out the stability of the estimates. These estimates performed well for univariate time series data on house prices for the US economy, are better than the constant time parameters as found out by Brown et al. (1997).

The existing literature on forecasting housing prices for the US and the UK mostly used univariate time series whereas (Kishor \& Marfatia, 2018; Mohan, Hutson, MacDonald, \& Lin, 2019) used multivariate time series for forecasting the growth of real housing prices along with other variables of interest like disposable income, industrial production, stock returns and interest rates for the 16 Organization of Economic Cooperation and Development countries hereafter named as OECD. Uncertainty is inevitable in any forecasting method, in the case of time series analysis, range forecast is a better measure than point forecasting methods. The range forecasting methods will give the ups and downs in the with the confidence interval about a series instead of a single predicted value. Fan chart was first used by the bank of England in 1996 for the inflation report and it gained atten- 
tion afterward. In this study fan chart is used to forecast the housing prices along with FDI and worker's remittances.

Usually, house prices appreciation is attributed to the increased income and population across the globe, apart from this foreign capital inflow plays a vital role, the popular sources are the foreign direct investment and the worker's remittances. The inflow of foreign direct investment in the Chinese housing market showed signs of growth in the housing sector tremendously. This rapid foreign investment in the housing market will overheat the economy by destabilizing the housing prices in the home country if it will not be properly channelized (Hui \& Chan, 2014). Similarly, the phenomena of rising housing prices were analyzed by Gholipour (2013) with the vector autoregression VAR model for nine years. The analysis confirmed that due to the inflow of foreign capital housing prices increase and it also increased in the 21 emerging economies.

There is a study conducted by Poon (2017) which has focused on key factors that affect foreign direct investment in the UK economy. It is rich enough to attract much of the tourists around the world so the property prices are not affected by the increase in the number of tourists, domestic income and interest rate are among the key factors which affect the housing prices. Feng, Lin, and Wang (2017) analyzed the impact on FDI and hot money on stock and house prices in China, the results confirmed that positive shock to hot money increased both stock and house prices, whereas the FDI shock increase house prices of the previous years. The OECD countries have experienced growth in foreign direct investment for the last 20 years but the results suggest that the FDI neither increases property price nor stimulates economic growth for short as well as long run (Gholipour, Al-Mulali, \& Mohammed, 2014).

The macroeconomic factors other than FDI like interest rate, real effective exchange rate, and stock returns also contribute to the appreciation of the house prices it is found by Mahalik and Mallick (2016) which used variance decomposition from the vector autoregression model for the Indian economy. The role of workers remittances is also significant in the appreciation of the housing prices, by using the quantile regression for the economy of Bangladesh analyzed both domestic and international sources of workers remittances. The house price volatility for the economy of Namibia is tested through autoregressive conditional heteroscedasticity and generalized autoregressive conditional heteroscedasticity. The results reveal that the lagged value of gross domestic product and mortgage caused housing prices to fluctuate (Kaulihowa \& Kamati, 2019).

In developing countries, people have lower levels of income just because of a lack of earning sources in the home country. The domestic economy's resources usually cannot employ its masses so people rely on going abroad for earning a handsome amount of money to finance their needs. People search for jobs abroad and the households save their income in a foreign country and spend the amount for necessary expenses along with building a house in the home country. It is one of the proper usage of the worker's remittances earned abroad. This increase in worker's remittances will increase the house building activity and eventually it will lead to house price appreciation in the home country. This has been done in Ghana where the level of income is low and the population is rapidly rising, it has created a housing shortage in the economy (Obeng-Odoom, 2010).

In the urban areas of Pakistan, a study used the hedonic pricing method, which con- 
cluded that when permanent income increase it affects housing demand rather than the increase in transitory income because people are reluctant to make purchasing decisions on the volatile income (Ahmad, Iqbal, \& Siddiqui, 2018). To forecast housing prices there are many factors both domestic and international which play a crucial role in the housing market. The motivation of the study is to analyze the behavior of the inflow of foreign capital inflow in the housing sector in the economy of Pakistan. The foreign direct investment and worker's remittances are taken into account to jointly forecast their impact on the housing prices.

This is the pioneering study that addresses the issue of forecasting housing prices. To the best of my knowledge, no one has until now tried to work on forecasting the housing prices for the economy of Pakistan. It provides me the novel opportunity to explore the topic firsthand.

\section{Methodology}

The problem of uncertainty prevails when any economic indicator is forecasted, despite taking in to account many spheres of forecasting. In this paper, we attempt to forecast house prices along with foreign direct inflow and worker's remittances for the economy of Pakistan. There are two strands related to forecasting point forecast and range forecast, the former will give only a single forecasted value and the latter gives us the range of values that might be used for future forecasting based on the probabilistic information embedded in them. To get the benefits of the high-frequency data we have to decompose the annual data set to a quarterly and monthly basis based on the technique proposed by Chow and Lin (1971).

Being a graphical representation fan charts provide the density forecast. It uses different lines and colorful bands to distinguish between multiple percentiles. The most popular percentiles used in the illustration of an estimated probability distribution of fan charts are the 10th, 30th, 60th, and 90th. These bands increase in size with the increase in uncertainty resultantly the graphical picture gets the shape of wider wings, it is the intuition that makes it popular as a fan chart.

Economic analysts frequently use the fan chart technique for forecasting economic aggregates because of its advantages over other methods. The bank of England used it the first time to forecast inflation in 1996, afterward it gained much popularity and it is used by the International Monetary Fund hereafter named IMF, to forecast many economic variables including the growth rate of the gross domestic product for global economies. This new technique is also used to forecast regional as well as aggregate trade volume of the economy of Pakistan (Jawaid, Waheed, et al., 2017), the current study uses it to forecast housing prices, FDI, and worker's remittances. To produce the fan chart for the housing prices forecast the methodology of Kannan and Elekdag (2009) is used in the following manner.

1. Growth forecast of housing prices $\lambda$

2. The historical forecast error variance is denoted by $\delta \lambda$ 
3. The Pearson skewness is computed as $\gamma \lambda$

4. The confidence interval is chosen at 30,60 , and 90 percent level

5. The 2-piece normal distribution shows variance and skewness parameters (as a central forecast mean is denoted by $\mu$ and the left and right standard deviations are shown by $\delta_{1}$ and $\delta_{2}$ respectively.

The 2-piece normal distribution density function (with a common mean for both sides of distribution is denoted by $\mu$, and standard deviations for each side is shown by $\delta_{1}$ and $\left.\delta_{2}\right)$.

$$
\begin{aligned}
& f(\lambda)=A \exp \left(-\frac{(\lambda-\mu)^{2}}{2 \delta_{1}^{2}}\right) \text { for } \lambda \leq \mu \\
& f(\lambda)=A \exp \left(-\frac{(\lambda-\mu)^{2}}{2 \delta_{1}^{2}}\right) \text { for } \lambda \leq \mu
\end{aligned}
$$

Where,

$$
\frac{\sqrt{2}\left(\delta_{1}+\delta_{2}\right)^{-1}}{\sqrt{\pi}}
$$

The mode of distribution is given by $\mu \neq \delta_{1}$ and $\delta_{2}$ prevails if the distribution is skewed. The 2-piece normal distribution mean, variance, and skewness is given by the following equations respectively.

$$
\begin{gathered}
E(\lambda)=\mu+\rho\left(\delta_{2}-\delta_{1}\right) \\
V(\lambda)=\delta_{1} \delta_{2}\left(1-\rho^{2}\right)\left(\delta_{2}-\delta_{1}\right)^{2} \\
\gamma(\lambda)=\rho\left(\delta_{2}-\delta_{1}\right)\left[\left(2 \rho^{2}-1\right)\left(\delta_{2}-\delta_{1}\right)^{2}\right]+\delta_{1} \delta_{2}
\end{gathered}
$$

Where,

$$
\rho=\sqrt{\frac{2}{\pi}}
$$

In equations 4,5 , and 6 , the mean $\mathrm{E}(\lambda)$, variance $\mathrm{V}(\lambda)$ and skewness $\gamma(\lambda)$ respectively, shown for the two-piece normal distribution. The two-piece normal distribution skewness coefficient is given by Blix and Sellin (1998) in the following manner:

$$
\gamma(\lambda)=\rho\left(\delta_{2}-\delta_{1}\right)
$$

It has simplified the work in calculating $\delta_{1}$ and $\delta_{2}$ as the coefficient of skewness in the 2-piece normal distribution interval for the fan chart. In the equation of variance $\mathrm{V}(\lambda)$ and skewness $\gamma(\lambda)$ we substitute the values for $\delta_{1}$ and $\delta_{2}$ we get:

$$
\delta_{1}^{2}+\rho \gamma \lambda \delta_{1}-\left[(1-\rho) \gamma \lambda^{2}+\delta \lambda^{2}\right]=0
$$


Where $\gamma \lambda$ is estimated skewness and $\delta \lambda$ is the variance of the 2-piece normal distribution. When we find out the standard deviation for the right side $\delta_{1}$ of the distribution, we can get $\delta_{2}$ easily by the approximate solution of equation 8 .

6. The confidence interval of the estimated point forecast for the variables of interest are drawn by the level of confidence (q), it is given as under:

$$
\begin{gathered}
z_{1}=\mu-\frac{\delta_{1}}{\delta_{2}}\left(z_{2}-\mu\right) \\
z_{2}=\mu-\delta_{2} \varphi^{-1}\left(\frac{1+q}{2}\right)
\end{gathered}
$$

Where $\varphi^{-1}$ refers to the opposite of standard normal distribution and its range is

\begin{tabular}{|c|c|c|c|c|c|c|}
\hline Variable & Obs. & Mean & Min. & Max. & Std. Dev. & ADF \\
\hline HP & 46 & 3.607 & 1.677 & 5.313 & 0.994 & $-5.026^{*}$ \\
\hline FDI & 46 & 0.808 & 0.046 & 3.668 & 0.794 & $-4.535^{*}$ \\
\hline WR & 46 & 5.191 & 1.454 & 10.248 & 2.142 & $-6.899^{*}$ \\
\hline
\end{tabular}
$\left(0<\varphi^{-1}<1\right)$. The details can get from Yu (2011); Camilleri and Vella (2015).

The data is available yearly on the variables of interest and it's taken from World Development Indicators, World Bank and Handbook of Statistics, State Bank of Pakistan. Table 1 shows the statistical properties of variables HP, FDI, WR which refers to the house prices, foreign direct investment as a percentage to GDP, worker's remittances as a percentage to GDP respectively. The data on these variables are available on an annual basis but they are converted into a quarterly and monthly basis to attain the benefits of high-frequency data and detailed analysis of the problem at hand.

\section{Fan Chart Analysis:}

This section covers the discussion of forecasting house prices along with two sources of foreign capital inflows namely foreign direct investment and worker's remittances in Pakistan. To get the benefits of the high power data, the series is usually available yearly but they were converted on a quarterly and monthly basis. 
Figure 1

Fan Chart of House Prices Growth (Annual Data)

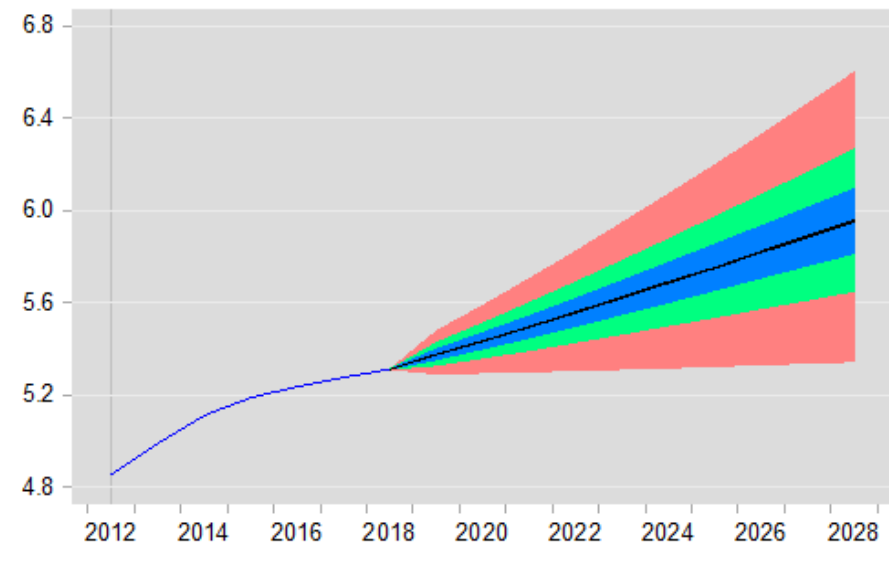

$90 \%$ Confindence Interv; $60 \%$ Confindence Interva $30 \%$ Confindence Interval

Figure 2

Fan Chart of Foreign Direct Investment Growth Rate (Annual Data)

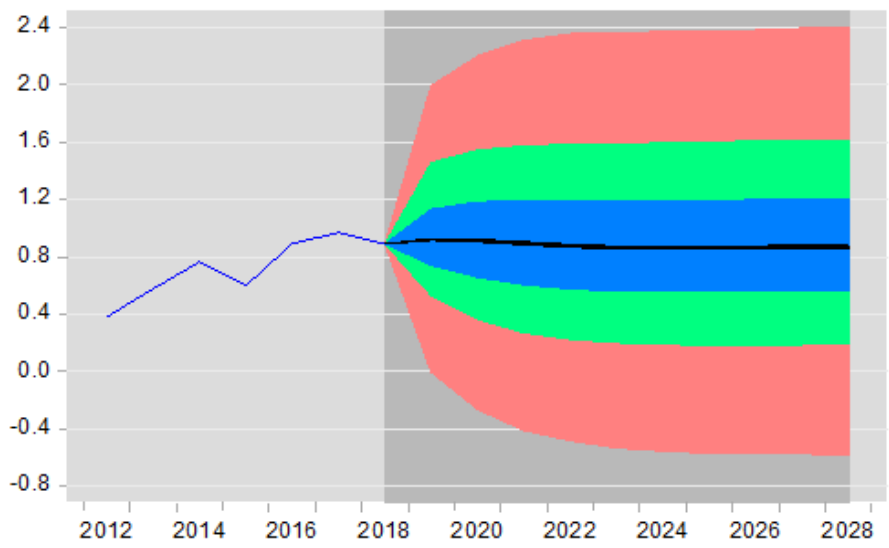

$90 \%$ Confindence Interva $60 \%$ Confidence Interval $30 \%$ Confidence Interval 
Figure 3

Fan Chart of Worker's Remittances Growth (Annual Data)

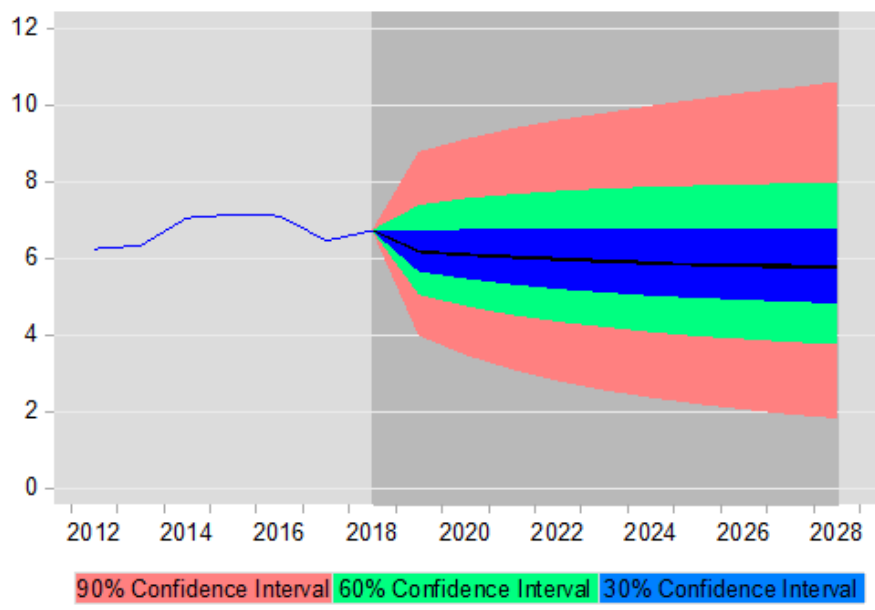

\section{Annual Data Analysis:}

The growth rate of house prices is stood at 5.63 percent from 2019 to 2028, this shown in Figure 1, 2, 3, and Tables 2, 3, and 4. The upside risk is evident from the coefficient of skewness in all the years of forecast. The average foreign direct investment growth rate stood at 0.88 from 2019 to 2028 and the average growth rate of worker's remittances is 6 percent for the same period. Skewness is showing upside risk in case of foreign direct investment whereas it also shows upside risk for the worker's remittances.

Table 2

Result of Fan Chart of House Prices Growth (Annual Data)

\begin{tabular}{|c|c|c|c|c|c|c|c|c|c|}
\hline \multirow[t]{3}{*}{ Year } & \multirow[t]{3}{*}{ Growth Rate } & \multirow[t]{3}{*}{ St. Dev } & \multirow[t]{3}{*}{ Skewness } & \multicolumn{6}{|c|}{ Confidence Interval } \\
\hline & & & & \multicolumn{2}{|c|}{30 percent } & \multicolumn{2}{|c|}{60 percent } & \multicolumn{2}{|c|}{90 percent } \\
\hline & & & & Lower & Upper & Lower & Upper & Lower & Upper \\
\hline 2019 & 5.377 & 0.057 & 0.299 & 5.355 & 5.4 & 5.332 & 5.428 & 5.293 & 5.479 \\
\hline 2020 & 5.435 & 0.089 & 0.184 & 5.402 & 5.47 & 5.363 & 5.512 & 5.298 & 5.589 \\
\hline 2021 & 5.496 & 0.123 & 0.125 & 5.45 & 5.544 & 5.396 & 5.6 & 5.303 & 5.705 \\
\hline 2022 & 5.559 & 0.158 & 0.086 & 5.5 & 5.62 & 5.431 & 5.691 & 5.308 & 5.825 \\
\hline 2023 & 5.624 & 0.193 & 0.075 & 5.552 & 5.697 & 5.466 & 5.783 & 5.315 & 5.948 \\
\hline 2024 & 5.69 & 0.229 & 0.058 & 5.604 & 5.776 & 5.503 & 5.877 & 5.319 & 6.073 \\
\hline 2025 & 5.753 & 0.266 & 0.069 & 5.657 & 5.855 & 5.54 & 5.974 & 5.327 & 6.2 \\
\hline 2026 & 5.822 & 0.304 & 0.069 & 5.71 & 5.935 & 5.577 & 6.07 & 5.333 & 6.332 \\
\hline 2027 & 5.889 & 0.342 & 0.086 & 5.764 & 6.015 & 5.614 & 6.168 & 5.341 & 6.466 \\
\hline 2028 & 5.957 & 0.381 & 0.1 & 5.816 & 6.095 & 5.652 & 6.266 & 5.347 & 6.602 \\
\hline
\end{tabular}

Source: Author's estimation 
Table 3

Result of Fan Chart of Foreign Direct Investment Growth (Annual Data)

\begin{tabular}{lccccccccc}
\hline Year & Growth Rate & St. Dev & Skewness & \multicolumn{3}{c}{ Confidence Interval } \\
& & & & & \multicolumn{3}{c}{ 30 percent } & 60 percent & 90 percent \\
& & & & Lower & Upper & Lower & Upper & Lower & Upper \\
\hline 2019 & 0.922 & 0.6 & 0.207 & 0.743 & 1.13 & 0.528 & 1.456 & -0.006 & 1.995 \\
2020 & 0.913 & 0.744 & 0.138 & 0.659 & 1.182 & 0.364 & 1.543 & -0.263 & 2.201 \\
2021 & 0.895 & 0.821 & 0.126 & 0.608 & 1.19 & 0.271 & 1.573 & -0.411 & 2.308 \\
2022 & 0.877 & 0.856 & 0.134 & 0.578 & 1.185 & 0.225 & 1.581 & -0.483 & 2.355 \\
2023 & 0.864 & 0.874 & 0.105 & 0.563 & 1.185 & 0.202 & 1.586 & -0.532 & 2.362 \\
2024 & 0.863 & 0.883 & 0.09 & 0.561 & 1.187 & 0.191 & 1.593 & -0.554 & 2.371 \\
2025 & 0.865 & 0.89 & 0.07 & 0.561 & 1.193 & 0.184 & 1.601 & -0.569 & 2.375 \\
2026 & 0.866 & 0.893 & 0.065 & 0.566 & 1.197 & 0.182 & 1.605 & -0.574 & 2.38 \\
2027 & 0.87 & 0.896 & 0.074 & 0.565 & 1.204 & 0.188 & 1.609 & -0.573 & 2.394 \\
2028 & 0.869 & 0.9 & 0.068 & 0.564 & 1.201 & 0.192 & 1.611 & -0.585 & 2.4 \\
\hline
\end{tabular}

Source: Author's estimation

Table 4

Result of Fan Chart of Worker's Remittances Growth (Annual Data)

\begin{tabular}{|c|c|c|c|c|c|c|c|c|c|}
\hline \multirow[t]{3}{*}{ Year } & \multirow[t]{3}{*}{ Growth Rate } & \multirow[t]{3}{*}{ St. Deviation } & \multirow[t]{3}{*}{ Skewness } & \multicolumn{6}{|c|}{ Confidence Interval } \\
\hline & & & & \multicolumn{2}{|c|}{30 percent } & \multicolumn{2}{|c|}{60 percent } & \multicolumn{2}{|c|}{90 percent } \\
\hline & & & & Lower & Upper & Lower & Upper & Lower & Upper \\
\hline 2019 & 6.171 & 1.44 & 0.297 & 5.668 & 6.688 & 5.074 & 7.365 & 4.003 & 8.76 \\
\hline 2020 & 6.092 & 1.704 & 0.226 & 5.489 & 6.733 & 4.771 & 7.544 & 3.494 & 9.089 \\
\hline 2021 & 6.031 & 1.906 & 0.213 & 5.339 & 6.753 & 4.541 & 7.646 & 3.112 & 9.367 \\
\hline 2022 & 5.977 & 2.067 & 0.217 & 5.218 & 6.74 & 4.363 & 7.731 & 2.81 & 9.592 \\
\hline 2023 & 5.919 & 2.194 & 0.223 & 5.128 & 6.744 & 4.22 & 7.793 & 2.571 & 9.771 \\
\hline 2024 & 5.876 & 2.31 & 0.252 & 5.041 & 6.733 & 4.089 & 7.84 & 2.376 & 9.964 \\
\hline 2025 & 5.819 & 2.411 & 0.28 & 4.982 & 6.739 & 3.984 & 7.873 & 2.208 & 10.136 \\
\hline 2026 & 5.813 & 2.498 & 0.301 & 4.935 & 6.733 & 3.915 & 7.905 & 2.071 & 10.307 \\
\hline 2027 & 5.789 & 2.575 & 0.308 & 4.879 & 6.734 & 3.827 & 7.927 & 1.934 & 10.431 \\
\hline 2028 & 5.764 & 2.648 & 0.343 & 4.845 & 6.734 & 3.771 & 7.953 & 1.838 & 10.589 \\
\hline
\end{tabular}

Source: Author's estimation

\section{Quarterly Data Analysis:}

In the case of quarterly data, the growth rate of house prices stood at 5.59 percent from 2018Q2 to 2028Q4, it is shown in Figures 4, 5, and 6. Tables 5, 6, and 7 shows the results of HP, FDI, and WR respectively ${ }^{2}$. The coefficient of skewness is positive except for the 3rd and 4th quarter of 2018; the 4th quarter of 2023 through the 2nd quarter of 2028 showed a negative sign of the coefficient. These particular negative magnitude quarters show downside risk except for the rest of the positive periods. The average growth rate of foreign direct investment is 0.85 percent from 2018Q2 to 2028Q4 however, the growth rate of worker's remittances is 6 percent for the same sample. Skewness is negative for all the periods for the growth rate of foreign direct investment except 3 quarters of the year 2018 which shows downside risk for the entire period of forecast. However, in case the growth rate of worker's remittances skewness shows positive values except for 2018Q2 to 2019Q2 that period showed a negative value of the coefficient of skewness which is associated with downside risk.

\footnotetext{
${ }^{2}$ Tables are given in Appendix 1.
} 


\section{Figure 4}

Fan Chart of House Prices Growth Rate (Quarterly Data)

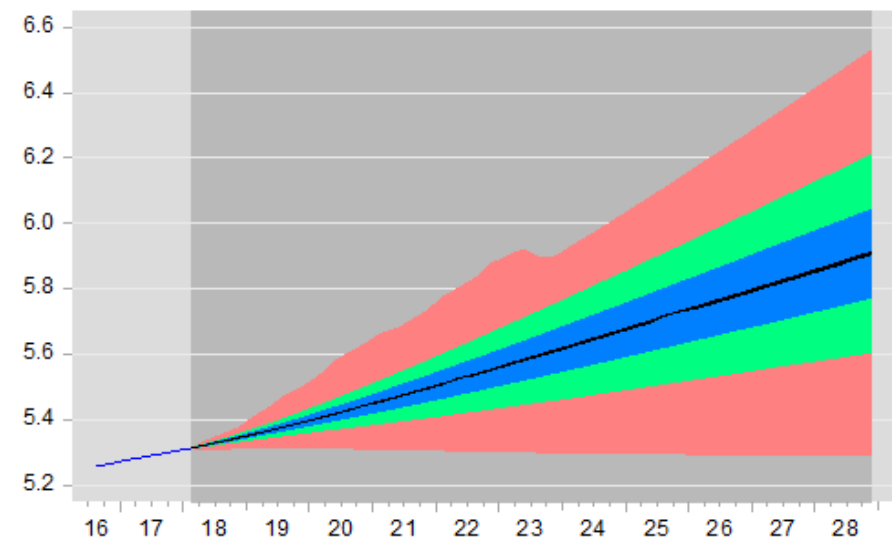

$90 \%$ Confidence Interval $60 \%$ Confidence Interval $30 \%$ Confidence Interval

\section{Figure 5}

Fan Chart of Foreign Direct Investment Growth Rate (Quarterly Data)

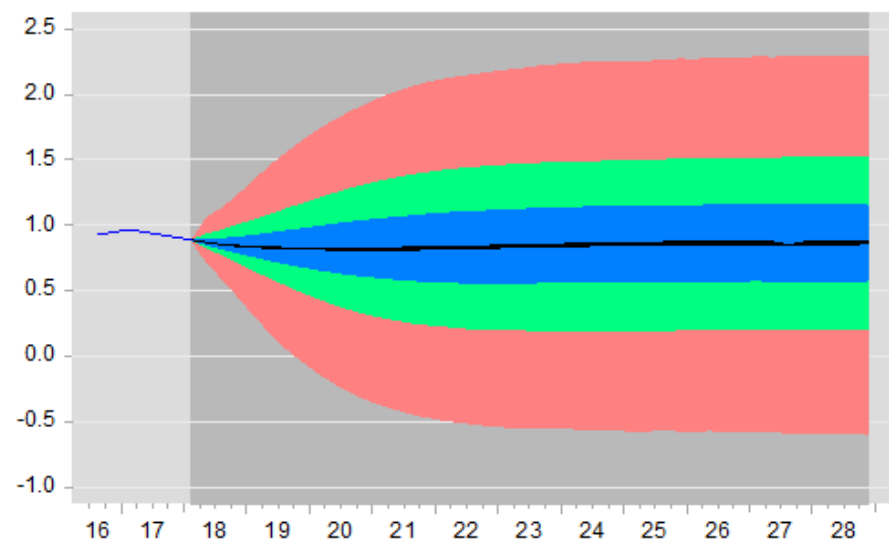

$90 \%$ Confidence Interval $60 \%$ Confidence Interval $30 \%$ Confidence Interval 


\section{Figure 6}

Fan Chart of Worker's Remittances of Growth Rate (Quarterly Data)

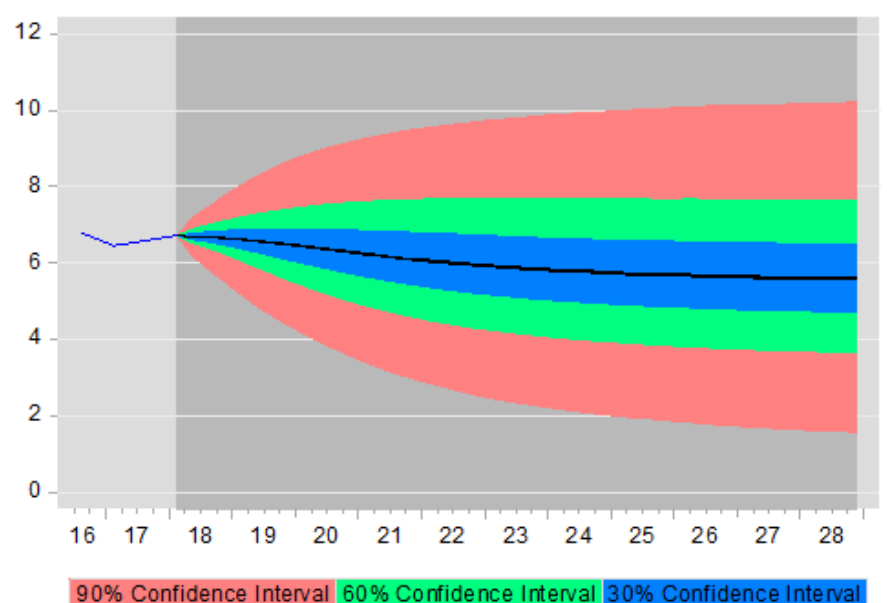

\section{Monthly Data Analysis:}

The analysis of monthly data shows that the growth rate of house prices is 5.59 percent from February 2018 to December 2028, this is reported in Figures 7, 8, and 9. Tables 8, 9, and 10 shows the results of HP, FDI and WR respectively ${ }^{3}$. The downside risk is evident from the negative value of skewness for the entire period. The average growth rate of foreign direct investment is 0.85 percent from 2nd month of 2018 to 12 th month of 2028 , the skewness is positive in the first 2 months of 2018 and from 1st month of 2025 till the end, except for the period of 4 th month 2018 to 12 th month of 2024 which shows negative value.

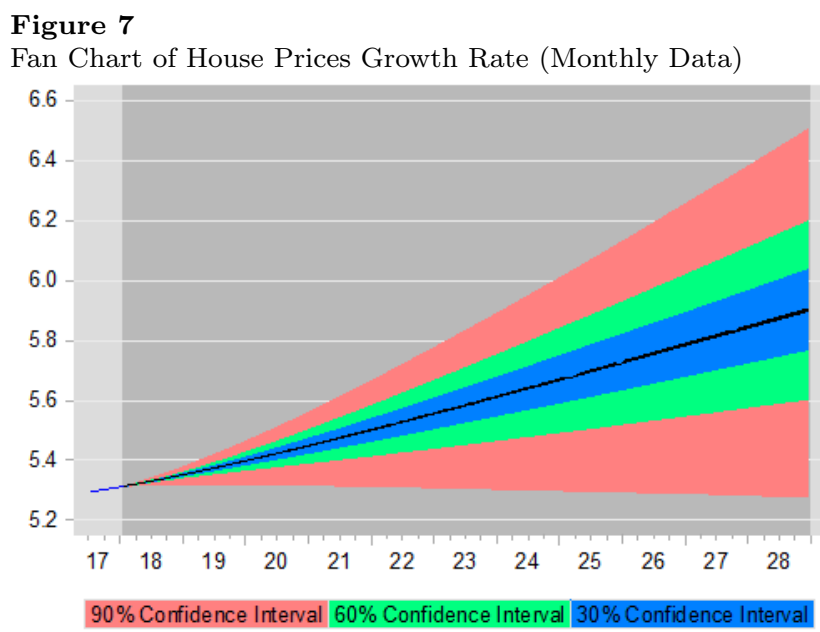

\footnotetext{
${ }^{3}$ Tables are given in Appendix 1.
} 
Whereas the average growth rate of worker's remittances is 6.04 percent for the same period under study, the skewness is negative from the 2 nd month of 2018 to the 3rd month of 2020 and positive from the 4th month of 2020 till the end of the period.

\section{Figure 8}

Fan Chart of Foreign Direct Investment Growth Rate (Monthly Data)

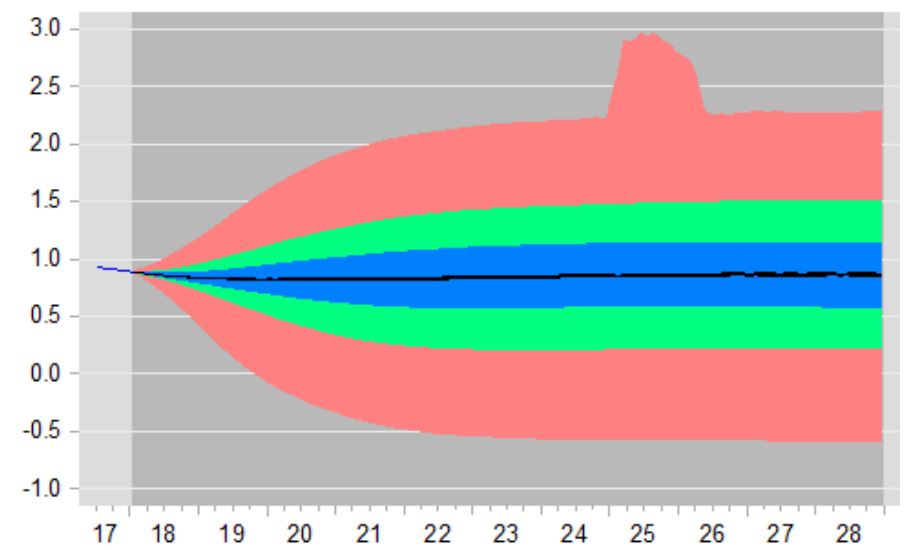

$90 \%$ Confidence Interval $60 \%$ Confidence Interval $30 \%$ Confidence Interval

Figure 9

Fan Chart of Worker's Remittances Growth (Monthly Data)

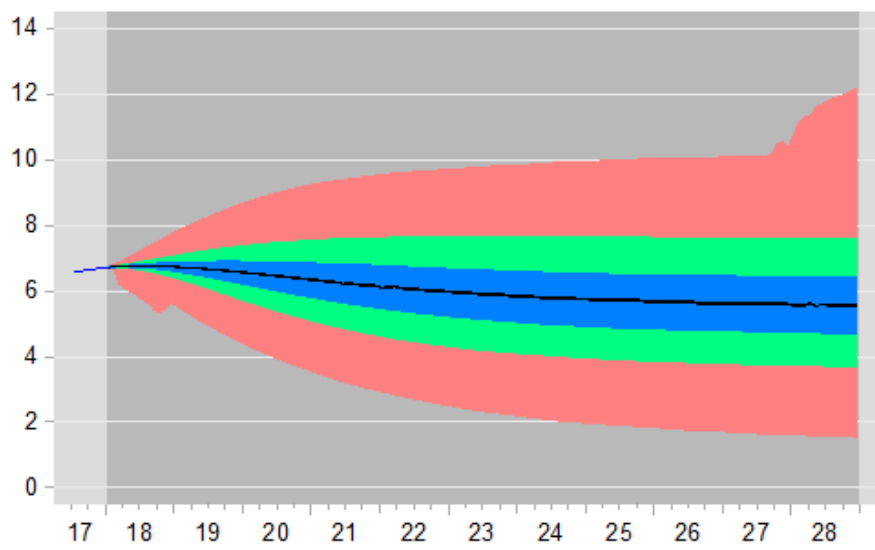

$90 \%$ Confidence Interval $60 \%$ Confidence Interval $30 \%$ Confidence Interval

\section{Conclusion and Policy Recommendations:}

The study compiles a combined analysis of yearly, quarterly, and monthly data for the growth rates of housing prices, foreign direct investment, and worker's remittances for the 
economy of Pakistan. The forecasting is done from 2019 to 2028 based on the sample data available from 1973 to 2018. This is the pioneering study that addressed the forecasting of housing prices and foreign capital inflow in Pakistan. Fan chart is used for forecasting it tells us not only the future forecasted value but also the uncertainty associated with that forecasted value. The advantage of using a range forecasting method like Fan Chart is that it provides upside and downside risk associated with the decision.

The house prices grew at 5.63 percent annually which is slightly higher than quarterly and monthly analysis. The foreign direct investment will grow with the same rate in the three strands of analysis at 0.85 percent. Similarly, the growth rate of worker's remittances stood at 6 percent and it is also the same in the annual, quarterly, and monthly analysis. The skewness showed upside risk in forecasting the housing prices annually, it showed negative in some quarters in the middle and end of the sample forecast, but it reported downside risk during monthly analysis. It has become volatile to invest in the housing sectors like investing stock market. The behavior of the foreign capital inflow is almost similar for both foreign direct investment and worker's remittances. Skewness for both the variables showed upside risk in annual analysis, while the quarterly data showed downside risk for the entire period except 3 quarters of 2018; monthly analysis showed mixed results.

The policymakers should plan in such a way that the inflow of foreign capital is encouraged as it serves as the income source for the economy. This inflow of foreign capital will also benefit as a multiplier effect on other ancillary sectors related to the housing. Housing is an important sector its development is directly related to the growth of gross domestic product through gross residential construction. There is only upside risk in annual data otherwise quarterly and monthly data shows downside risk, this phenomenon compels public authorities to pay attention to the housing sector, its upside risk can be minimized with policy directives as it shows downside risk with the close breakup.

The government of Pakistan should make a housing policy regularly which has not been carried out for a long time so that it should devise ways to invest in the housing sector. Its aim should be clear and it gives proper channels through which foreign funds are invested in the housing sector. There is a dire need of time to establish a separate institution in the form of a bank dedicated to the purpose of housing finance which conducts surveys and advises the government about the financing needs in various cities. The House Building Finance Company Limited is working but there is more area to be covered.

This analysis of the housing sector can be performed for domestic and commercial units separately and it will serve for further research. There is a huge potential in the housing sector to contribute substantially to the economic development of the country. 


\section{Appendix 1}

Table 5

Result of Fan Chart of House Price Growth (Quarterly Data)

\begin{tabular}{|c|c|c|c|c|c|c|c|c|c|}
\hline \multirow[t]{3}{*}{ Year } & \multirow[t]{3}{*}{ Growth Rate } & \multirow[t]{3}{*}{ St. Dev } & \multirow[t]{3}{*}{ Skewness } & \multicolumn{6}{|c|}{ Confidence Interval } \\
\hline & & & & \multicolumn{2}{|c|}{30 percent } & \multicolumn{2}{|c|}{60 percent } & \multicolumn{2}{|c|}{90 percent } \\
\hline & & & & Lower & Upper & Lower & Upper & Lower & Upper \\
\hline 2018Q2 & 5.324 & 0.007 & 0.016 & 5.322 & 5.325 & 5.32 & 5.327 & 5.311 & 5.337 \\
\hline 2018Q3 & 5.334 & 0.012 & -0.101 & 5.331 & 5.337 & 5.328 & 5.34 & 5.312 & 5.355 \\
\hline 2018Q4 & 5.345 & 0.017 & -0.172 & 5.341 & 5.349 & 5.334 & 5.355 & 5.313 & 5.374 \\
\hline 2019Q1 & 5.356 & 0.027 & 0.57 & 5.35 & 5.362 & 5.341 & 5.371 & 5.314 & 5.411 \\
\hline 2019Q2 & 5.368 & 0.036 & 0.639 & 5.359 & 5.376 & 5.347 & 5.388 & 5.314 & 5.439 \\
\hline 2019Q3 & 5.379 & 0.047 & 0.851 & 5.368 & 5.391 & 5.353 & 5.405 & 5.314 & 5.476 \\
\hline 2019Q4 & 5.392 & 0.053 & 0.658 & 5.378 & 5.405 & 5.359 & 5.423 & 5.313 & 5.498 \\
\hline 2020Q1 & 5.404 & 0.063 & 0.703 & 5.387 & 5.42 & 5.365 & 5.442 & 5.313 & 5.53 \\
\hline 2020Q2 & 5.417 & 0.076 & 0.896 & 5.397 & 5.436 & 5.371 & 5.46 & 5.312 & 5.576 \\
\hline $2020 \mathrm{Q} 3$ & 5.43 & 0.085 & 0.846 & 5.407 & 5.452 & 5.377 & 5.48 & 5.312 & 5.605 \\
\hline 2020Q4 & 5.444 & 0.093 & 0.732 & 5.417 & 5.468 & 5.383 & 5.499 & 5.311 & 5.631 \\
\hline 2021Q1 & 5.456 & 0.102 & 0.729 & 5.427 & 5.484 & 5.389 & 5.519 & 5.311 & 5.662 \\
\hline 2021Q2 & 5.469 & 0.108 & 0.54 & 5.437 & 5.501 & 5.395 & 5.54 & 5.31 & 5.677 \\
\hline 2021Q3 & 5.483 & 0.116 & 0.493 & 5.447 & 5.518 & 5.402 & 5.56 & 5.309 & 5.705 \\
\hline 2021Q4 & 5.497 & 0.126 & 0.481 & 5.457 & 5.535 & 5.408 & 5.581 & 5.308 & 5.736 \\
\hline $2022 \mathrm{Q} 1$ & 5.511 & 0.138 & 0.549 & 5.468 & 5.552 & 5.414 & 5.602 & 5.307 & 5.777 \\
\hline 2022Q2 & 5.528 & 0.146 & 0.475 & 5.478 & 5.569 & 5.421 & 5.623 & 5.306 & 5.804 \\
\hline 2022Q3 & 5.539 & 0.156 & 0.477 & 5.489 & 5.586 & 5.427 & 5.644 & 5.306 & 5.834 \\
\hline 2022Q4 & 5.553 & 0.168 & 0.543 & 5.5 & 5.603 & 5.434 & 5.665 & 5.305 & 5.877 \\
\hline 2023Q1 & 5.568 & 0.175 & 0.451 & 5.511 & 5.621 & 5.441 & 5.687 & 5.304 & 5.898 \\
\hline 2023Q2 & 5.581 & 0.183 & 0.393 & 5.521 & 5.638 & 5.447 & 5.709 & 5.302 & 5.921 \\
\hline 2023Q3 & 5.596 & 0.178 & 0.046 & 5.532 & 5.656 & 5.454 & 5.73 & 5.301 & 5.896 \\
\hline $2023 Q 4$ & 5.61 & 0.181 & -0.12 & 5.544 & 5.674 & 5.461 & 5.752 & 5.3 & 5.897 \\
\hline $2024 \mathrm{Q} 1$ & 5.625 & 0.19 & -0.11 & 5.555 & 5.692 & 5.468 & 5.775 & 5.3 & 5.928 \\
\hline 2024Q2 & 5.639 & 0.199 & -0.11 & 5.566 & 5.71 & 5.475 & 5.797 & 5.299 & 5.957 \\
\hline 2024Q3 & 5.654 & 0.209 & -0.103 & 5.577 & 5.728 & 5.482 & 5.819 & 5.299 & 5.987 \\
\hline 2024Q4 & 5.669 & 0.218 & -0.097 & 5.588 & 5.746 & 5.489 & 5.842 & 5.298 & 6.017 \\
\hline $2025 \mathrm{Q} 1$ & 5.684 & 0.228 & -0.093 & 5.6 & 5.765 & 5.496 & 5.864 & 5.298 & 6.048 \\
\hline 2025Q2 & 5.699 & 0.237 & -0.089 & 5.611 & 5.783 & 5.504 & 5.886 & 5.297 & 6.078 \\
\hline 2025Q3 & 5.718 & 0.247 & -0.1 & 5.622 & 5.801 & 5.511 & 5.909 & 5.297 & 6.109 \\
\hline 2025Q4 & 5.732 & 0.256 & -0.091 & 5.634 & 5.82 & 5.518 & 5.931 & 5.296 & 6.141 \\
\hline $2026 \mathrm{Q} 1$ & 5.743 & 0.266 & -0.068 & 5.645 & 5.838 & 5.526 & 5.954 & 5.295 & 6.172 \\
\hline 2026Q2 & 5.758 & 0.276 & -0.064 & 5.657 & 5.856 & 5.533 & 5.977 & 5.294 & 6.204 \\
\hline 2026Q3 & 5.773 & 0.285 & -0.056 & 5.668 & 5.875 & 5.54 & 6 & 5.294 & 6.235 \\
\hline 2026Q4 & 5.787 & 0.295 & -0.049 & 5.679 & 5.894 & 5.547 & 6.023 & 5.294 & 6.266 \\
\hline 2027Q1 & 5.802 & 0.305 & -0.036 & 5.691 & 5.912 & 5.555 & 6.046 & 5.294 & 6.299 \\
\hline 2027Q2 & 5.818 & 0.314 & -0.029 & 5.702 & 5.931 & 5.563 & 6.069 & 5.294 & 6.331 \\
\hline 2027Q3 & 5.832 & 0.325 & -0.024 & 5.714 & 5.949 & 5.569 & 6.092 & 5.292 & 6.364 \\
\hline 2027Q4 & 5.847 & 0.335 & -0.02 & 5.726 & 5.968 & 5.577 & 6.115 & 5.292 & 6.396 \\
\hline 2028Q1 & 5.862 & 0.345 & -0.012 & 5.738 & 5.986 & 5.585 & 6.138 & 5.291 & 6.429 \\
\hline 2028Q2 & 5.877 & 0.354 & -0.005 & 5.749 & 6.004 & 5.592 & 6.161 & 5.291 & 6.461 \\
\hline 2028Q3 & 5.893 & 0.365 & 0.001 & 5.761 & 6.023 & 5.599 & 6.184 & 5.291 & 6.495 \\
\hline 2028Q4 & 5.908 & 0.375 & 0.012 & 5.773 & 6.042 & 5.606 & 6.208 & 5.291 & 6.528 \\
\hline
\end{tabular}

Source: Author's estimation 
Table 6

Result of Fan Chart of Foreign Direct Investment Growth (Quarterly Data)

\begin{tabular}{|c|c|c|c|c|c|c|c|c|c|}
\hline \multirow[t]{3}{*}{ Year } & \multirow[t]{3}{*}{ Growth Rate } & \multirow[t]{3}{*}{ St. Dev } & \multirow[t]{3}{*}{ Skewness } & \multicolumn{6}{|c|}{ Confidence Interval } \\
\hline & & & & \multicolumn{2}{|c|}{30 percent } & \multicolumn{2}{|c|}{60 percent } & \multicolumn{2}{|c|}{90 percent } \\
\hline & & & & Lower & Upper & Lower & Upper & Lower & Upper \\
\hline 2018Q2 & 0.868 & 0.099 & 0.365 & 0.851 & 0.892 & 0.828 & 0.933 & 0.711 & 1.061 \\
\hline 2018Q3 & 0.852 & 0.158 & 0.02 & 0.82 & 0.898 & 0.774 & 0.965 & 0.583 & 1.137 \\
\hline 2018Q4 & 0.843 & 0.227 & -0.059 & 0.79 & 0.907 & 0.716 & 1.003 & 0.448 & 1.238 \\
\hline 2019Q1 & 0.835 & 0.299 & -0.101 & 0.761 & 0.921 & 0.656 & 1.041 & 0.309 & 1.347 \\
\hline 2019Q2 & 0.829 & 0.369 & -0.106 & 0.733 & 0.938 & 0.599 & 1.081 & 0.179 & 1.456 \\
\hline 2019Q3 & 0.825 & 0.433 & -0.124 & 0.707 & 0.956 & 0.544 & 1.123 & 0.061 & 1.553 \\
\hline 2019Q4 & 0.823 & 0.489 & -0.11 & 0.685 & 0.972 & 0.493 & 1.162 & -0.035 & 1.641 \\
\hline 2020Q1 & 0.821 & 0.54 & -0.099 & 0.664 & 0.989 & 0.444 & 1.201 & -0.122 & 1.723 \\
\hline 2020Q2 & 0.82 & 0.587 & -0.094 & 0.644 & 1.005 & 0.4 & 1.238 & -0.2 & 1.796 \\
\hline 2020Q3 & 0.82 & 0.627 & -0.09 & 0.628 & 1.022 & 0.362 & 1.275 & -0.266 & 1.86 \\
\hline $2020 \mathrm{Q} 4$ & 0.82 & 0.663 & -0.08 & 0.614 & 1.035 & 0.329 & 1.308 & -0.322 & 1.918 \\
\hline 2021Q1 & 0.821 & 0.694 & -0.065 & 0.602 & 1.047 & 0.301 & 1.338 & -0.368 & 1.971 \\
\hline 2021Q2 & 0.821 & 0.72 & -0.053 & 0.591 & 1.059 & 0.279 & 1.36 & -0.405 & 2.016 \\
\hline 2021Q3 & 0.823 & 0.743 & -0.046 & 0.582 & 1.07 & 0.258 & 1.383 & -0.438 & 2.055 \\
\hline $2021 \mathrm{Q} 4$ & 0.825 & 0.762 & -0.04 & 0.573 & 1.083 & 0.243 & 1.401 & -0.465 & 2.089 \\
\hline 2022Q1 & 0.827 & 0.776 & -0.042 & 0.569 & 1.092 & 0.232 & 1.418 & -0.485 & 2.112 \\
\hline $2022 \mathrm{Q} 2$ & 0.83 & 0.788 & -0.044 & 0.565 & 1.099 & 0.221 & 1.431 & -0.504 & 2.133 \\
\hline 2022Q3 & 0.834 & 0.798 & -0.041 & 0.563 & 1.106 & 0.211 & 1.442 & -0.514 & 2.15 \\
\hline $2022 \mathrm{Q} 4$ & 0.837 & 0.808 & -0.052 & 0.562 & 1.11 & 0.209 & 1.448 & -0.534 & 2.166 \\
\hline 2023Q1 & 0.839 & 0.814 & -0.044 & 0.563 & 1.115 & 0.204 & 1.458 & -0.539 & 2.183 \\
\hline 2023Q2 & 0.842 & 0.821 & -0.046 & 0.564 & 1.122 & 0.203 & 1.465 & -0.549 & 2.197 \\
\hline 2023Q3 & 0.844 & 0.826 & -0.032 & 0.566 & 1.126 & 0.199 & 1.472 & -0.548 & 2.212 \\
\hline $2023 \mathrm{Q} 4$ & 0.847 & 0.83 & -0.025 & 0.567 & 1.13 & 0.198 & 1.477 & -0.549 & 2.223 \\
\hline 2024Q1 & 0.851 & 0.833 & -0.018 & 0.571 & 1.134 & 0.197 & 1.482 & -0.548 & 2.233 \\
\hline 2024Q2 & 0.852 & 0.838 & -0.029 & 0.573 & 1.138 & 0.197 & 1.484 & -0.56 & 2.241 \\
\hline $2024 \mathrm{Q} 3$ & 0.856 & 0.839 & -0.038 & 0.574 & 1.142 & 0.197 & 1.486 & -0.562 & 2.243 \\
\hline 2024Q4 & 0.857 & 0.842 & -0.033 & 0.576 & 1.144 & 0.199 & 1.491 & -0.564 & 2.252 \\
\hline 2025Q1 & 0.86 & 0.843 & -0.045 & 0.575 & 1.143 & 0.196 & 1.493 & -0.569 & 2.249 \\
\hline $2025 \mathrm{Q} 2$ & 0.859 & 0.843 & -0.039 & 0.577 & 1.145 & 0.198 & 1.496 & -0.566 & 2.252 \\
\hline 2025Q3 & 0.862 & 0.844 & -0.03 & 0.577 & 1.145 & 0.199 & 1.499 & -0.563 & 2.259 \\
\hline $2025 \mathrm{Q} 4$ & 0.862 & 0.847 & -0.026 & 0.578 & 1.147 & 0.204 & 1.502 & -0.566 & 2.269 \\
\hline 2026Q1 & 0.864 & 0.848 & -0.033 & 0.576 & 1.149 & 0.202 & 1.505 & -0.568 & 2.267 \\
\hline 2026Q2 & 0.863 & 0.848 & -0.024 & 0.576 & 1.152 & 0.204 & 1.508 & -0.565 & 2.271 \\
\hline 2026Q3 & 0.865 & 0.853 & -0.028 & 0.577 & 1.152 & 0.203 & 1.512 & -0.575 & 2.28 \\
\hline $2026 \mathrm{Q} 4$ & 0.864 & 0.852 & -0.028 & 0.579 & 1.151 & 0.204 & 1.513 & -0.571 & 2.277 \\
\hline 2027Q1 & 0.865 & 0.854 & -0.031 & 0.58 & 1.153 & 0.207 & 1.512 & -0.578 & 2.284 \\
\hline 2027Q2 & 0.865 & 0.854 & -0.032 & 0.577 & 1.153 & 0.21 & 1.511 & -0.577 & 2.282 \\
\hline 2027Q3 & 0.847 & 0.856 & -0.011 & 0.575 & 1.156 & 0.211 & 1.515 & -0.58 & 2.285 \\
\hline $2027 \mathrm{Q} 4$ & 0.864 & 0.856 & -0.037 & 0.575 & 1.156 & 0.211 & 1.517 & -0.584 & 2.285 \\
\hline 2028Q1 & 0.864 & 0.858 & -0.033 & 0.575 & 1.157 & 0.21 & 1.514 & -0.586 & 2.289 \\
\hline 2028Q2 & 0.866 & 0.858 & -0.033 & 0.575 & 1.156 & 0.209 & 1.515 & -0.585 & 2.29 \\
\hline 2028Q3 & 0.867 & 0.86 & -0.033 & 0.575 & 1.154 & 0.207 & 1.517 & -0.589 & 2.294 \\
\hline $2028 \mathrm{Q} 4$ & 0.869 & 0.861 & -0.043 & 0.574 & 1.154 & 0.206 & 1.519 & -0.594 & 2.292 \\
\hline
\end{tabular}

Source: Author's estimation 
Table 7

Result of Fan Chart of Worker's Remittances Growth (Quarterly Data)

\begin{tabular}{|c|c|c|c|c|c|c|c|c|c|}
\hline \multirow[t]{3}{*}{ Year } & \multirow[t]{3}{*}{ Growth Rate } & \multirow[t]{3}{*}{ St. Dev } & \multirow[t]{3}{*}{ Skewness } & \multicolumn{6}{|c|}{ Confidence Interval } \\
\hline & & & & \multicolumn{2}{|c|}{30 percent } & \multicolumn{2}{|c|}{60 percent } & \multicolumn{2}{|c|}{90 percent } \\
\hline & & & & Lower & Upper & Lower & Upper & Lower & Upper \\
\hline 2018Q2 & 6.69 & 0.294 & -0.099 & 6.616 & 6.769 & 6.521 & 6.89 & 6.171 & 7.194 \\
\hline 2018Q3 & 6.679 & 0.474 & -0.132 & 6.552 & 6.814 & 6.391 & 7.001 & 5.837 & 7.48 \\
\hline 2018Q4 & 6.652 & 0.652 & -0.088 & 6.473 & 6.845 & 6.238 & 7.1 & 5.509 & 7.76 \\
\hline 2019Q1 & 6.622 & 0.824 & -0.053 & 6.382 & 6.868 & 6.073 & 7.192 & 5.192 & 8.022 \\
\hline 2019Q2 & 6.58 & 0.986 & -0.018 & 6.286 & 6.883 & 5.9 & 7.273 & 4.89 & 8.261 \\
\hline 2019Q3 & 6.532 & 1.13 & 0.027 & 6.189 & 6.891 & 5.731 & 7.344 & 4.626 & 8.473 \\
\hline 2019Q4 & 6.486 & 1.261 & 0.06 & 6.086 & 6.892 & 5.566 & 7.405 & 4.386 & 8.654 \\
\hline 2020Q1 & 6.44 & 1.381 & 0.067 & 5.993 & 6.893 & 5.412 & 7.458 & 4.152 & 8.811 \\
\hline 2020Q2 & 6.389 & 1.492 & 0.081 & 5.897 & 6.887 & 5.26 & 7.507 & 3.938 & 8.949 \\
\hline 2020Q3 & 6.339 & 1.587 & 0.096 & 5.81 & 6.877 & 5.123 & 7.544 & 3.751 & 9.067 \\
\hline 2020Q4 & 6.288 & 1.676 & 0.105 & 5.723 & 6.859 & 4.996 & 7.578 & 3.569 & 9.17 \\
\hline 2021Q1 & 6.235 & 1.761 & 0.111 & 5.64 & 6.845 & 4.881 & 7.603 & 3.391 & 9.266 \\
\hline 2021Q2 & 6.188 & 1.834 & 0.115 & 5.568 & 6.829 & 4.776 & 7.629 & 3.236 & 9.346 \\
\hline 2021Q3 & 6.126 & 1.903 & 0.138 & 5.493 & 6.81 & 4.678 & 7.638 & 3.093 & 9.43 \\
\hline 2021Q4 & 6.098 & 1.963 & 0.139 & 5.427 & 6.797 & 4.587 & 7.652 & 2.969 & 9.497 \\
\hline 2022Q1 & 6.057 & 2.016 & 0.139 & 5.365 & 6.781 & 4.5 & 7.669 & 2.851 & 9.544 \\
\hline 2022Q2 & 6.019 & 2.063 & 0.152 & 5.309 & 6.765 & 4.428 & 7.673 & 2.753 & 9.601 \\
\hline 2022Q3 & 5.984 & 2.113 & 0.146 & 5.258 & 6.747 & 4.359 & 7.678 & 2.632 & 9.647 \\
\hline 2022Q4 & 5.953 & 2.157 & 0.149 & 5.206 & 6.73 & 4.295 & 7.685 & 2.533 & 9.692 \\
\hline 2023Q1 & 5.92 & 2.196 & 0.164 & 5.165 & 6.708 & 4.242 & 7.687 & 2.455 & 9.746 \\
\hline 2023Q2 & 5.889 & 2.226 & 0.165 & 5.13 & 6.69 & 4.195 & 7.688 & 2.378 & 9.772 \\
\hline 2023Q3 & 5.859 & 2.256 & 0.178 & 5.089 & 6.67 & 4.144 & 7.679 & 2.315 & 9.807 \\
\hline 2023Q4 & 5.836 & 2.286 & 0.191 & 5.055 & 6.655 & 4.098 & 7.677 & 2.256 & 9.85 \\
\hline 2024Q1 & 5.81 & 2.317 & 0.204 & 5.024 & 6.641 & 4.055 & 7.666 & 2.191 & 9.898 \\
\hline 2024Q2 & 5.791 & 2.337 & 0.203 & 4.997 & 6.628 & 4.015 & 7.663 & 2.141 & 9.91 \\
\hline 2024Q3 & 5.776 & 2.361 & 0.203 & 4.97 & 6.612 & 3.982 & 7.666 & 2.085 & 9.936 \\
\hline 2024Q4 & 5.755 & 2.382 & 0.208 & 4.946 & 6.596 & 3.951 & 7.668 & 2.038 & 9.957 \\
\hline 2025Q1 & 5.734 & 2.402 & 0.207 & 4.919 & 6.588 & 3.924 & 7.662 & 1.985 & 9.976 \\
\hline 2025Q2 & 5.707 & 2.423 & 0.225 & 4.9 & 6.581 & 3.897 & 7.661 & 1.95 & 10.014 \\
\hline 2025Q3 & 5.701 & 2.44 & 0.232 & 4.877 & 6.574 & 3.872 & 7.659 & 1.921 & 10.041 \\
\hline 2025Q4 & 5.688 & 2.455 & 0.229 & 4.862 & 6.565 & 3.844 & 7.656 & 1.881 & 10.053 \\
\hline 2026Q1 & 5.69 & 2.473 & 0.226 & 4.845 & 6.558 & 3.818 & 7.659 & 1.846 & 10.074 \\
\hline 2026Q2 & 5.662 & 2.487 & 0.233 & 4.829 & 6.548 & 3.797 & 7.661 & 1.81 & 10.089 \\
\hline 2026Q3 & 5.654 & 2.505 & 0.237 & 4.814 & 6.544 & 3.78 & 7.656 & 1.775 & 10.117 \\
\hline 2026Q4 & 5.646 & 2.522 & 0.241 & 4.796 & 6.533 & 3.77 & 7.656 & 1.738 & 10.144 \\
\hline 2027Q1 & 5.633 & 2.525 & 0.235 & 4.784 & 6.525 & 3.75 & 7.657 & 1.719 & 10.132 \\
\hline 2027Q2 & 5.626 & 2.534 & 0.236 & 4.766 & 6.516 & 3.734 & 7.656 & 1.698 & 10.136 \\
\hline 2027Q3 & 5.614 & 2.542 & 0.235 & 4.755 & 6.511 & 3.719 & 7.653 & 1.673 & 10.14 \\
\hline 2027Q4 & 5.611 & 2.555 & 0.237 & 4.748 & 6.504 & 3.705 & 7.655 & 1.648 & 10.161 \\
\hline 2028Q1 & 5.602 & 2.562 & 0.237 & 4.743 & 6.499 & 3.689 & 7.642 & 1.627 & 10.167 \\
\hline 2028Q2 & 5.598 & 2.568 & 0.24 & 4.735 & 6.496 & 3.684 & 7.643 & 1.616 & 10.179 \\
\hline 2028Q3 & 5.59 & 2.577 & 0.238 & 4.728 & 6.5 & 3.68 & 7.641 & 1.592 & 10.189 \\
\hline 2028Q4 & 5.585 & 2.588 & 0.245 & 4.722 & 6.497 & 3.659 & 7.639 & 1.577 & 10.212 \\
\hline
\end{tabular}

Source: Author's estimation 
Table 8

Result of Fan Chart of House Price Growth (Monthly Data)

\begin{tabular}{|c|c|c|c|c|c|c|c|c|c|}
\hline \multirow[t]{3}{*}{ Year } & \multirow[t]{3}{*}{ Growth Rate } & \multirow[t]{3}{*}{ St. Dev } & \multirow[t]{3}{*}{ Skewness } & \multicolumn{6}{|c|}{ Confidence Interval } \\
\hline & & & & \multicolumn{2}{|c|}{30 percent } & \multicolumn{2}{|c|}{60 percent } & \multicolumn{2}{|c|}{90 percent } \\
\hline & & & & Lower & Upper & Lower & Upper & Lower & Upper \\
\hline 2018M02 & 5.316 & 0.001 & -1.272 & 5.316 & 5.316 & 5.316 & 5.316 & 5.315 & 5.317 \\
\hline 2018M03 & 5.319 & 0.001 & -0.784 & 5.319 & 5.32 & 5.319 & 5.32 & 5.316 & 5.322 \\
\hline 2018M04 & 5.323 & 0.003 & -0.476 & 5.322 & 5.323 & 5.322 & 5.324 & 5.317 & 5.327 \\
\hline 2018M05 & 5.326 & 0.004 & -0.4 & 5.325 & 5.326 & 5.324 & 5.327 & 5.318 & 5.333 \\
\hline 2018M06 & 5.329 & 0.005 & -0.343 & 5.328 & 5.33 & 5.327 & 5.331 & 5.319 & 5.338 \\
\hline 2018M07 & 5.333 & 0.007 & -0.325 & 5.332 & 5.334 & 5.33 & 5.335 & 5.319 & 5.344 \\
\hline 2018M08 & 5.336 & 0.008 & -0.316 & 5.335 & 5.337 & 5.332 & 5.339 & 5.32 & 5.35 \\
\hline 2018M09 & 5.34 & 0.01 & -0.331 & 5.338 & 5.341 & 5.335 & 5.344 & 5.321 & 5.356 \\
\hline 2018M10 & 5.343 & 0.012 & -0.349 & 5.341 & 5.345 & 5.337 & 5.348 & 5.321 & 5.362 \\
\hline $2018 \mathrm{M} 11$ & 5.347 & 0.013 & -0.338 & 5.344 & 5.349 & 5.34 & 5.353 & 5.321 & 5.369 \\
\hline $2018 \mathrm{M} 12$ & 5.35 & 0.015 & -0.355 & 5.347 & 5.353 & 5.342 & 5.358 & 5.321 & 5.375 \\
\hline 2019M01 & 5.354 & 0.017 & -0.36 & 5.35 & 5.358 & 5.344 & 5.363 & 5.321 & 5.381 \\
\hline 2019M02 & 5.358 & 0.019 & -0.372 & 5.353 & 5.362 & 5.346 & 5.368 & 5.321 & 5.388 \\
\hline 2019M03 & 5.361 & 0.021 & -0.377 & 5.356 & 5.366 & 5.349 & 5.373 & 5.321 & 5.395 \\
\hline 2019M04 & 5.365 & 0.023 & -0.327 & 5.359 & 5.371 & 5.351 & 5.378 & 5.321 & 5.402 \\
\hline 2019M05 & 5.369 & 0.025 & -0.368 & 5.363 & 5.375 & 5.353 & 5.384 & 5.322 & 5.409 \\
\hline 2019M06 & 5.373 & 0.027 & -0.371 & 5.366 & 5.38 & 5.355 & 5.389 & 5.321 & 5.416 \\
\hline 2019M07 & 5.377 & 0.029 & -0.369 & 5.369 & 5.384 & 5.357 & 5.395 & 5.321 & 5.423 \\
\hline 2019M08 & 5.381 & 0.032 & -0.375 & 5.372 & 5.389 & 5.359 & 5.4 & 5.321 & 5.43 \\
\hline 2019M09 & 5.385 & 0.034 & -0.369 & 5.375 & 5.394 & 5.361 & 5.406 & 5.321 & 5.437 \\
\hline 2019M10 & 5.389 & 0.036 & -0.366 & 5.378 & 5.398 & 5.363 & 5.412 & 5.321 & 5.445 \\
\hline 2019M11 & 5.393 & 0.038 & -0.36 & 5.381 & 5.403 & 5.365 & 5.418 & 5.321 & 5.452 \\
\hline 2019M12 & 5.397 & 0.041 & -0.353 & 5.384 & 5.408 & 5.367 & 5.423 & 5.32 & 5.46 \\
\hline 2020M01 & 5.401 & 0.043 & -0.349 & 5.388 & 5.413 & 5.369 & 5.429 & 5.32 & 5.468 \\
\hline 2020M02 & 5.405 & 0.046 & -0.342 & 5.391 & 5.418 & 5.371 & 5.435 & 5.32 & 5.475 \\
\hline 2020M03 & 5.409 & 0.048 & -0.346 & 5.394 & 5.423 & 5.373 & 5.441 & 5.319 & 5.483 \\
\hline 2020M04 & 5.413 & 0.051 & -0.339 & 5.397 & 5.428 & 5.375 & 5.448 & 5.319 & 5.491 \\
\hline $2020 \mathrm{M} 05$ & 5.417 & 0.053 & -0.334 & 5.4 & 5.433 & 5.377 & 5.454 & 5.319 & 5.499 \\
\hline 2020M06 & 5.421 & 0.056 & -0.33 & 5.403 & 5.438 & 5.379 & 5.46 & 5.319 & 5.507 \\
\hline 2020M07 & 5.425 & 0.058 & -0.326 & 5.407 & 5.444 & 5.381 & 5.466 & 5.318 & 5.515 \\
\hline 2020M08 & 5.43 & 0.061 & -0.324 & 5.41 & 5.449 & 5.383 & 5.473 & 5.318 & 5.523 \\
\hline 2020M09 & 5.434 & 0.063 & -0.319 & 5.413 & 5.454 & 5.385 & 5.479 & 5.318 & 5.531 \\
\hline $2020 \mathrm{M} 10$ & 5.438 & 0.066 & -0.314 & 5.416 & 5.459 & 5.387 & 5.485 & 5.318 & 5.539 \\
\hline $2020 \mathrm{M} 11$ & 5.442 & 0.069 & -0.306 & 5.42 & 5.465 & 5.389 & 5.492 & 5.318 & 5.548 \\
\hline $2020 \mathrm{M} 12$ & 5.447 & 0.071 & -0.298 & 5.423 & 5.47 & 5.391 & 5.499 & 5.317 & 5.556 \\
\hline 2021M01 & 5.451 & 0.074 & -0.299 & 5.426 & 5.475 & 5.393 & 5.505 & 5.317 & 5.564 \\
\hline 2021M02 & 5.456 & 0.077 & -0.293 & 5.43 & 5.481 & 5.395 & 5.512 & 5.317 & 5.573 \\
\hline 2021M03 & 5.46 & 0.079 & -0.288 & 5.433 & 5.486 & 5.397 & 5.518 & 5.317 & 5.581 \\
\hline 2021M04 & 5.464 & 0.082 & -0.282 & 5.436 & 5.492 & 5.399 & 5.525 & 5.316 & 5.59 \\
\hline 2021M05 & 5.469 & 0.085 & -0.276 & 5.439 & 5.497 & 5.401 & 5.532 & 5.316 & 5.599 \\
\hline 2021M06 & 5.473 & 0.087 & -0.271 & 5.443 & 5.502 & 5.403 & 5.538 & 5.316 & 5.607 \\
\hline 2021M07 & 5.478 & 0.09 & -0.264 & 5.446 & 5.508 & 5.405 & 5.545 & 5.316 & 5.616 \\
\hline 2021M08 & 5.482 & 0.093 & -0.261 & 5.45 & 5.513 & 5.407 & 5.551 & 5.316 & 5.625 \\
\hline 2021M09 & 5.486 & 0.096 & -0.257 & 5.453 & 5.519 & 5.409 & 5.558 & 5.315 & 5.634 \\
\hline $2021 \mathrm{M} 10$ & 5.491 & 0.099 & -0.251 & 5.456 & 5.524 & 5.411 & 5.565 & 5.315 & 5.642 \\
\hline 2021M11 & 5.495 & 0.101 & -0.247 & 5.46 & 5.53 & 5.413 & 5.572 & 5.315 & 5.652 \\
\hline $2021 \mathrm{M} 12$ & 5.5 & 0.104 & -0.246 & 5.463 & 5.536 & 5.415 & 5.579 & 5.314 & 5.66 \\
\hline 2022M01 & 5.504 & 0.107 & -0.238 & 5.467 & 5.541 & 5.417 & 5.585 & 5.314 & 5.67 \\
\hline 2022M02 & 5.509 & 0.11 & -0.239 & 5.47 & 5.547 & 5.419 & 5.592 & 5.313 & 5.679 \\
\hline 2022M03 & 5.513 & 0.113 & -0.239 & 5.473 & 5.553 & 5.421 & 5.599 & 5.313 & 5.688 \\
\hline 2022M04 & 5.518 & 0.116 & -0.232 & 5.477 & 5.558 & 5.424 & 5.606 & 5.312 & 5.697 \\
\hline 2022M05 & 5.521 & 0.119 & -0.218 & 5.48 & 5.564 & 5.426 & 5.613 & 5.312 & 5.706 \\
\hline 2022M06 & 5.527 & 0.122 & -0.228 & 5.484 & 5.57 & 5.428 & 5.62 & 5.312 & 5.715 \\
\hline 2022M07 & 5.53 & 0.125 & -0.209 & 5.487 & 5.575 & 5.43 & 5.627 & 5.311 & 5.725 \\
\hline 2022M08 & 5.536 & 0.128 & -0.22 & 5.491 & 5.581 & 5.432 & 5.634 & 5.311 & 5.734 \\
\hline 2022M09 & 5.541 & 0.131 & -0.218 & 5.494 & 5.587 & 5.434 & 5.641 & 5.311 & 5.743 \\
\hline $2022 \mathrm{M} 10$ & 5.545 & 0.134 & -0.213 & 5.498 & 5.593 & 5.436 & 5.648 & 5.31 & 5.753 \\
\hline $2022 \mathrm{M} 11$ & 5.55 & 0.137 & -0.212 & 5.502 & 5.599 & 5.438 & 5.655 & 5.31 & 5.762 \\
\hline 2022M12 & 5.552 & 0.14 & -0.194 & 5.505 & 5.605 & 5.441 & 5.662 & 5.31 & 5.771 \\
\hline
\end{tabular}


Table 8

Cont'd

\begin{tabular}{|c|c|c|c|c|c|c|c|c|c|}
\hline \multirow[t]{3}{*}{ Year } & \multirow[t]{3}{*}{ Growth Rate } & \multirow[t]{3}{*}{ St. Dev } & \multirow[t]{3}{*}{ Skewness } & \multicolumn{6}{|c|}{ Confidence Interval } \\
\hline & & & & \multicolumn{2}{|c|}{30 percent } & \multicolumn{2}{|c|}{60 percent } & \multicolumn{2}{|c|}{90 percent } \\
\hline & & & & Lower & Upper & Lower & Upper & Lower & Upper \\
\hline 2023M01 & 5.559 & 0.143 & -0.206 & 5.509 & 5.61 & 5.443 & 5.669 & 5.309 & 5.781 \\
\hline 2023M02 & 5.564 & 0.146 & -0.207 & 5.512 & 5.616 & 5.445 & 5.677 & 5.309 & 5.79 \\
\hline 2023M03 & 5.568 & 0.149 & -0.203 & 5.516 & 5.622 & 5.447 & 5.684 & 5.308 & 5.8 \\
\hline 2023M04 & 5.571 & 0.152 & -0.188 & 5.519 & 5.628 & 5.449 & 5.691 & 5.308 & 5.809 \\
\hline 2023M05 & 5.576 & 0.155 & -0.189 & 5.523 & 5.634 & 5.451 & 5.698 & 5.307 & 5.819 \\
\hline 2023M06 & 5.579 & 0.158 & -0.176 & 5.526 & 5.64 & 5.453 & 5.705 & 5.307 & 5.829 \\
\hline 2023M07 & 5.587 & 0.161 & -0.19 & 5.53 & 5.645 & 5.456 & 5.712 & 5.307 & 5.838 \\
\hline 2023M08 & 5.59 & 0.164 & -0.18 & 5.534 & 5.651 & 5.458 & 5.72 & 5.306 & 5.848 \\
\hline 2023M09 & 5.595 & 0.167 & -0.184 & 5.537 & 5.657 & 5.46 & 5.727 & 5.306 & 5.857 \\
\hline $2023 \mathrm{M} 10$ & 5.601 & 0.17 & -0.189 & 5.541 & 5.663 & 5.462 & 5.734 & 5.306 & 5.866 \\
\hline 2023M11 & 5.606 & 0.173 & -0.188 & 5.545 & 5.669 & 5.464 & 5.741 & 5.305 & 5.876 \\
\hline $2023 \mathrm{M} 12$ & 5.61 & 0.176 & -0.181 & 5.548 & 5.675 & 5.466 & 5.748 & 5.305 & 5.886 \\
\hline 2024M01 & 5.615 & 0.179 & -0.184 & 5.552 & 5.681 & 5.469 & 5.756 & 5.304 & 5.895 \\
\hline 2024M02 & 5.62 & 0.182 & -0.18 & 5.555 & 5.687 & 5.471 & 5.763 & 5.304 & 5.905 \\
\hline 2024M03 & 5.625 & 0.185 & -0.178 & 5.559 & 5.692 & 5.473 & 5.77 & 5.303 & 5.915 \\
\hline 2024M04 & 5.63 & 0.189 & -0.174 & 5.562 & 5.698 & 5.475 & 5.778 & 5.303 & 5.925 \\
\hline 2024M05 & 5.634 & 0.192 & -0.173 & 5.566 & 5.704 & 5.477 & 5.785 & 5.302 & 5.935 \\
\hline 2024M06 & 5.639 & 0.195 & -0.169 & 5.569 & 5.71 & 5.48 & 5.792 & 5.302 & 5.945 \\
\hline 2024M07 & 5.644 & 0.198 & -0.164 & 5.573 & 5.716 & 5.482 & 5.8 & 5.302 & 5.954 \\
\hline 2024M08 & 5.645 & 0.201 & -0.149 & 5.577 & 5.722 & 5.484 & 5.807 & 5.301 & 5.964 \\
\hline 2024M09 & 5.653 & 0.204 & -0.162 & 5.58 & 5.728 & 5.486 & 5.814 & 5.301 & 5.974 \\
\hline $2024 \mathrm{M} 10$ & 5.658 & 0.207 & -0.159 & 5.584 & 5.734 & 5.489 & 5.822 & 5.301 & 5.984 \\
\hline $2024 \mathrm{M} 11$ & 5.663 & 0.21 & -0.158 & 5.588 & 5.74 & 5.491 & 5.829 & 5.301 & 5.994 \\
\hline 2024M12 & 5.667 & 0.213 & -0.154 & 5.591 & 5.746 & 5.493 & 5.836 & 5.3 & 6.003 \\
\hline 2025M01 & 5.673 & 0.217 & -0.155 & 5.595 & 5.752 & 5.495 & 5.844 & 5.3 & 6.013 \\
\hline 2025M02 & 5.675 & 0.22 & -0.141 & 5.598 & 5.758 & 5.498 & 5.851 & 5.299 & 6.023 \\
\hline 2025M03 & 5.677 & 0.223 & -0.129 & 5.602 & 5.764 & 5.5 & 5.858 & 5.299 & 6.034 \\
\hline 2025M04 & 5.685 & 0.226 & -0.139 & 5.606 & 5.77 & 5.502 & 5.865 & 5.298 & 6.044 \\
\hline 2025M05 & 5.691 & 0.229 & -0.145 & 5.609 & 5.776 & 5.504 & 5.873 & 5.298 & 6.054 \\
\hline 2025M06 & 5.696 & 0.232 & -0.142 & 5.613 & 5.782 & 5.506 & 5.88 & 5.298 & 6.064 \\
\hline $2025 \mathrm{M} 07$ & 5.701 & 0.236 & -0.136 & 5.617 & 5.788 & 5.509 & 5.887 & 5.298 & 6.074 \\
\hline 2025M08 & 5.706 & 0.239 & -0.137 & 5.62 & 5.794 & 5.511 & 5.895 & 5.297 & 6.084 \\
\hline 2025M09 & 5.711 & 0.242 & -0.132 & 5.624 & 5.8 & 5.514 & 5.902 & 5.297 & 6.095 \\
\hline 2025M10 & 5.715 & 0.245 & -0.13 & 5.628 & 5.806 & 5.516 & 5.91 & 5.296 & 6.105 \\
\hline $2025 \mathrm{M} 11$ & 5.72 & 0.249 & -0.126 & 5.631 & 5.812 & 5.518 & 5.917 & 5.296 & 6.116 \\
\hline $2025 \mathrm{M} 12$ & 5.72 & 0.252 & -0.106 & 5.635 & 5.818 & 5.52 & 5.925 & 5.295 & 6.126 \\
\hline 2026M01 & 5.73 & 0.255 & -0.128 & 5.639 & 5.824 & 5.523 & 5.932 & 5.294 & 6.136 \\
\hline 2026M02 & 5.735 & 0.258 & -0.123 & 5.642 & 5.83 & 5.525 & 5.94 & 5.294 & 6.146 \\
\hline $2026 \mathrm{M} 03$ & 5.74 & 0.261 & -0.121 & 5.646 & 5.836 & 5.527 & 5.947 & 5.294 & 6.156 \\
\hline 2026M04 & 5.745 & 0.265 & -0.121 & 5.65 & 5.842 & 5.53 & 5.955 & 5.293 & 6.166 \\
\hline 2026M05 & 5.75 & 0.268 & -0.12 & 5.653 & 5.848 & 5.532 & 5.962 & 5.292 & 6.176 \\
\hline 2026M06 & 5.755 & 0.271 & -0.118 & 5.657 & 5.854 & 5.535 & 5.97 & 5.292 & 6.187 \\
\hline 2026M07 & 5.76 & 0.275 & -0.116 & 5.661 & 5.86 & 5.537 & 5.977 & 5.291 & 6.198 \\
\hline 2026M08 & 5.764 & 0.278 & -0.111 & 5.665 & 5.866 & 5.539 & 5.985 & 5.291 & 6.209 \\
\hline 2026M09 & 5.77 & 0.281 & -0.108 & 5.668 & 5.872 & 5.542 & 5.992 & 5.291 & 6.219 \\
\hline $2026 \mathrm{M} 10$ & 5.775 & 0.284 & -0.103 & 5.672 & 5.878 & 5.544 & 6 & 5.291 & 6.23 \\
\hline 2026M11 & 5.779 & 0.288 & -0.103 & 5.676 & 5.884 & 5.546 & 6.007 & 5.29 & 6.24 \\
\hline 2026M12 & 5.784 & 0.291 & -0.101 & 5.679 & 5.89 & 5.548 & 6.015 & 5.29 & 6.251 \\
\hline 2027M01 & 5.789 & 0.294 & -0.102 & 5.683 & 5.896 & 5.551 & 6.022 & 5.289 & 6.261 \\
\hline 2027M02 & 5.794 & 0.297 & -0.099 & 5.687 & 5.902 & 5.553 & 6.03 & 5.289 & 6.271 \\
\hline 2027M03 & 5.799 & 0.301 & -0.097 & 5.691 & 5.908 & 5.555 & 6.038 & 5.289 & 6.282 \\
\hline 2027M04 & 5.804 & 0.304 & -0.092 & 5.695 & 5.914 & 5.557 & 6.045 & 5.289 & 6.292 \\
\hline 2027M05 & 5.809 & 0.307 & -0.091 & 5.699 & 5.92 & 5.559 & 6.053 & 5.288 & 6.303 \\
\hline 2027M06 & 5.814 & 0.31 & -0.091 & 5.702 & 5.926 & 5.562 & 6.06 & 5.288 & 6.313 \\
\hline 2027M07 & 5.819 & 0.314 & -0.092 & 5.706 & 5.932 & 5.564 & 6.068 & 5.287 & 6.323 \\
\hline 2027M08 & 5.824 & 0.317 & -0.089 & 5.71 & 5.938 & 5.567 & 6.075 & 5.287 & 6.333 \\
\hline 2027M09 & 5.828 & 0.32 & -0.089 & 5.713 & 5.944 & 5.569 & 6.083 & 5.286 & 6.344 \\
\hline 2027M10 & 5.829 & 0.324 & -0.074 & 5.717 & 5.951 & 5.572 & 6.091 & 5.285 & 6.355 \\
\hline 2027M11 & 5.838 & 0.327 & -0.086 & 5.721 & 5.957 & 5.574 & 6.098 & 5.285 & 6.365 \\
\hline
\end{tabular}


Table 8

Cont'd

\begin{tabular}{cccccccccc}
\hline Year & Growth Rate & St. Dev & Skewness & \multicolumn{7}{c}{ Confidence Interval } \\
\hline & & & & 30 percent & 60 percent & 90 percent \\
\cline { 5 - 9 } & & & & Lower & Upper & Lower & Upper & Lower & Upper \\
\hline 2027M12 & 5.843 & 0.331 & -0.084 & 5.725 & 5.963 & 5.576 & 6.106 & 5.284 & 6.376 \\
2028M01 & 5.848 & 0.334 & -0.081 & 5.728 & 5.969 & 5.579 & 6.113 & 5.283 & 6.387 \\
2028M02 & 5.853 & 0.337 & -0.077 & 5.732 & 5.975 & 5.581 & 6.121 & 5.283 & 6.398 \\
2028M03 & 5.858 & 0.341 & -0.074 & 5.736 & 5.981 & 5.584 & 6.129 & 5.283 & 6.409 \\
2028M04 & 5.863 & 0.344 & -0.075 & 5.74 & 5.987 & 5.586 & 6.136 & 5.282 & 6.419 \\
2028M05 & 5.868 & 0.347 & -0.075 & 5.743 & 5.994 & 5.588 & 6.144 & 5.281 & 6.43 \\
2028M06 & 5.872 & 0.351 & -0.072 & 5.747 & 6 & 5.59 & 6.151 & 5.281 & 6.44 \\
2028M07 & 5.877 & 0.354 & -0.071 & 5.751 & 6.006 & 5.593 & 6.159 & 5.281 & 6.451 \\
2028M08 & 5.882 & 0.357 & -0.066 & 5.755 & 6.012 & 5.595 & 6.167 & 5.282 & 6.461 \\
2028M09 & 5.887 & 0.361 & -0.061 & 5.759 & 6.018 & 5.598 & 6.175 & 5.282 & 6.473 \\
2028M10 & 5.892 & 0.364 & -0.058 & 5.762 & 6.024 & 5.6 & 6.182 & 5.282 & 6.484 \\
2028M11 & 5.897 & 0.367 & -0.054 & 5.766 & 6.03 & 5.602 & 6.19 & 5.282 & 6.495 \\
2028M12 & 5.902 & 0.37 & -0.054 & 5.77 & 6.036 & 5.605 & 6.198 & 5.281 & 6.505 \\
\hline S0 & & & & & & & &
\end{tabular}

Source: Author's estimation 
Table 9

Result of Fan Chart of Foreign Direct Investment Growth (Monthly Data)

\begin{tabular}{|c|c|c|c|c|c|c|c|c|c|}
\hline \multirow[t]{3}{*}{ Year } & \multirow[t]{3}{*}{ Growth Rate } & \multirow[t]{3}{*}{ St. Dev } & \multirow[t]{3}{*}{ Skewness } & \multicolumn{6}{|c|}{ Confidence Interval } \\
\hline & & & & \multicolumn{2}{|c|}{30 percent } & \multicolumn{2}{|c|}{60 percent } & \multicolumn{2}{|c|}{90 percent } \\
\hline & & & & Lower & Upper & Lower & Upper & Lower & Upper \\
\hline 2018M02 & 0.882 & 0.011 & 0.786 & 0.88 & 0.884 & 0.878 & 0.889 & 0.866 & 0.906 \\
\hline 2018M03 & 0.876 & 0.023 & 0.148 & 0.873 & 0.88 & 0.869 & 0.888 & 0.837 & 0.919 \\
\hline 2018M04 & 0.871 & 0.039 & -0.142 & 0.865 & 0.878 & 0.858 & 0.89 & 0.8 & 0.94 \\
\hline 2018M05 & 0.865 & 0.054 & -0.162 & 0.857 & 0.876 & 0.847 & 0.893 & 0.766 & 0.962 \\
\hline 2018M06 & 0.861 & 0.072 & -0.196 & 0.849 & 0.875 & 0.834 & 0.898 & 0.728 & 0.987 \\
\hline 2018M07 & 0.857 & 0.091 & -0.224 & 0.841 & 0.875 & 0.821 & 0.904 & 0.688 & 1.015 \\
\hline 2018M08 & 0.853 & 0.11 & -0.247 & 0.833 & 0.875 & 0.808 & 0.91 & 0.646 & 1.044 \\
\hline 2018M09 & 0.849 & 0.131 & -0.297 & 0.825 & 0.876 & 0.793 & 0.919 & 0.601 & 1.073 \\
\hline 2018M10 & 0.846 & 0.153 & -0.329 & 0.817 & 0.878 & 0.777 & 0.928 & 0.556 & 1.102 \\
\hline $2018 \mathrm{M} 11$ & 0.843 & 0.174 & -0.354 & 0.809 & 0.881 & 0.761 & 0.938 & 0.511 & 1.133 \\
\hline $2018 \mathrm{M} 12$ & 0.84 & 0.197 & -0.391 & 0.801 & 0.884 & 0.744 & 0.948 & 0.463 & 1.164 \\
\hline 2019M01 & 0.838 & 0.22 & -0.398 & 0.793 & 0.887 & 0.727 & 0.959 & 0.417 & 1.197 \\
\hline 2019M02 & 0.836 & 0.243 & -0.418 & 0.786 & 0.891 & 0.709 & 0.971 & 0.368 & 1.23 \\
\hline 2019M03 & 0.832 & 0.267 & -0.426 & 0.778 & 0.895 & 0.691 & 0.984 & 0.318 & 1.264 \\
\hline 2019M04 & 0.832 & 0.291 & -0.421 & 0.77 & 0.899 & 0.673 & 0.997 & 0.271 & 1.301 \\
\hline 2019M05 & 0.831 & 0.316 & -0.418 & 0.762 & 0.903 & 0.654 & 1.009 & 0.222 & 1.338 \\
\hline 2019M06 & 0.829 & 0.34 & -0.402 & 0.754 & 0.909 & 0.636 & 1.023 & 0.178 & 1.375 \\
\hline 2019M07 & 0.828 & 0.362 & -0.39 & 0.746 & 0.914 & 0.618 & 1.036 & 0.135 & 1.411 \\
\hline 2019M08 & 0.827 & 0.385 & -0.373 & 0.738 & 0.919 & 0.599 & 1.05 & 0.095 & 1.446 \\
\hline 2019M09 & 0.826 & 0.407 & -0.346 & 0.73 & 0.925 & 0.582 & 1.063 & 0.056 & 1.484 \\
\hline 2019M10 & 0.825 & 0.427 & -0.323 & 0.723 & 0.93 & 0.564 & 1.076 & 0.021 & 1.518 \\
\hline 2019M11 & 0.824 & 0.447 & -0.308 & 0.716 & 0.935 & 0.547 & 1.09 & -0.013 & 1.55 \\
\hline 2019M12 & 0.824 & 0.465 & -0.29 & 0.708 & 0.941 & 0.53 & 1.104 & -0.043 & 1.58 \\
\hline 2020M01 & 0.824 & 0.484 & -0.28 & 0.701 & 0.947 & 0.514 & 1.117 & -0.076 & 1.611 \\
\hline 2020M02 & 0.824 & 0.502 & -0.256 & 0.694 & 0.953 & 0.498 & 1.13 & -0.104 & 1.643 \\
\hline 2020M03 & 0.824 & 0.518 & -0.244 & 0.687 & 0.959 & 0.481 & 1.143 & -0.131 & 1.669 \\
\hline 2020M04 & 0.824 & 0.535 & -0.226 & 0.68 & 0.964 & 0.466 & 1.156 & -0.157 & 1.699 \\
\hline 2020M05 & 0.825 & 0.551 & -0.203 & 0.674 & 0.97 & 0.451 & 1.169 & -0.18 & 1.729 \\
\hline 2020M06 & 0.825 & 0.566 & -0.185 & 0.667 & 0.976 & 0.436 & 1.181 & -0.201 & 1.754 \\
\hline 2020M07 & 0.825 & 0.58 & -0.177 & 0.66 & 0.981 & 0.421 & 1.193 & -0.224 & 1.778 \\
\hline 2020M08 & 0.825 & 0.595 & -0.17 & 0.655 & 0.987 & 0.408 & 1.205 & -0.248 & 1.803 \\
\hline 2020M09 & 0.826 & 0.609 & -0.152 & 0.649 & 0.992 & 0.395 & 1.217 & -0.266 & 1.828 \\
\hline $2020 \mathrm{M} 10$ & 0.825 & 0.621 & -0.142 & 0.644 & 0.996 & 0.38 & 1.228 & -0.285 & 1.849 \\
\hline $2020 \mathrm{M} 11$ & 0.826 & 0.634 & -0.137 & 0.639 & 1.002 & 0.367 & 1.239 & -0.304 & 1.87 \\
\hline $2020 \mathrm{M} 12$ & 0.826 & 0.644 & -0.128 & 0.634 & 1.006 & 0.355 & 1.249 & -0.319 & 1.887 \\
\hline 2021M01 & 0.826 & 0.656 & -0.13 & 0.63 & 1.012 & 0.343 & 1.26 & -0.338 & 1.905 \\
\hline 2021M02 & 0.829 & 0.666 & -0.129 & 0.625 & 1.017 & 0.332 & 1.27 & -0.354 & 1.922 \\
\hline 2021M03 & 0.827 & 0.677 & -0.127 & 0.621 & 1.022 & 0.323 & 1.281 & -0.371 & 1.937 \\
\hline 2021M04 & 0.828 & 0.686 & -0.127 & 0.617 & 1.027 & 0.314 & 1.291 & -0.386 & 1.953 \\
\hline 2021M05 & 0.827 & 0.696 & -0.117 & 0.613 & 1.031 & 0.305 & 1.301 & -0.398 & 1.969 \\
\hline 2021M06 & 0.829 & 0.704 & -0.115 & 0.608 & 1.036 & 0.297 & 1.312 & -0.409 & 1.983 \\
\hline 2021M07 & 0.829 & 0.713 & -0.111 & 0.606 & 1.04 & 0.289 & 1.322 & -0.422 & 1.998 \\
\hline 2021M08 & 0.829 & 0.721 & -0.107 & 0.603 & 1.045 & 0.282 & 1.33 & -0.433 & 2.012 \\
\hline 2021M09 & 0.83 & 0.728 & -0.101 & 0.6 & 1.05 & 0.275 & 1.337 & -0.441 & 2.025 \\
\hline $2021 \mathrm{M} 10$ & 0.83 & 0.735 & -0.099 & 0.597 & 1.054 & 0.269 & 1.344 & -0.453 & 2.038 \\
\hline 2021M11 & 0.83 & 0.742 & -0.103 & 0.596 & 1.058 & 0.264 & 1.352 & -0.465 & 2.047 \\
\hline $2021 \mathrm{M} 12$ & 0.83 & 0.748 & -0.096 & 0.594 & 1.062 & 0.258 & 1.36 & -0.471 & 2.06 \\
\hline 2022M01 & 0.829 & 0.753 & -0.091 & 0.591 & 1.066 & 0.253 & 1.366 & -0.477 & 2.067 \\
\hline 2022M02 & 0.832 & 0.758 & -0.092 & 0.589 & 1.07 & 0.25 & 1.373 & -0.482 & 2.076 \\
\hline 2022M03 & 0.832 & 0.763 & -0.096 & 0.587 & 1.073 & 0.248 & 1.379 & -0.491 & 2.083 \\
\hline 2022M04 & 0.833 & 0.767 & -0.092 & 0.586 & 1.074 & 0.243 & 1.383 & -0.498 & 2.092 \\
\hline 2022M05 & 0.834 & 0.772 & -0.096 & 0.585 & 1.078 & 0.24 & 1.389 & -0.505 & 2.099 \\
\hline 2022M06 & 0.833 & 0.776 & -0.1 & 0.584 & 1.081 & 0.237 & 1.394 & -0.512 & 2.103 \\
\hline 2022M07 & 0.834 & 0.78 & -0.104 & 0.585 & 1.084 & 0.235 & 1.4 & -0.518 & 2.109 \\
\hline 2022M08 & 0.835 & 0.784 & -0.09 & 0.584 & 1.088 & 0.231 & 1.404 & -0.518 & 2.12 \\
\hline 2022M09 & 0.838 & 0.786 & -0.096 & 0.583 & 1.09 & 0.228 & 1.409 & -0.522 & 2.123 \\
\hline $2022 \mathrm{M} 10$ & 0.837 & 0.79 & -0.089 & 0.583 & 1.093 & 0.227 & 1.414 & -0.525 & 2.132 \\
\hline $2022 \mathrm{M} 11$ & 0.839 & 0.793 & -0.094 & 0.583 & 1.096 & 0.226 & 1.418 & -0.532 & 2.137 \\
\hline 2022M12 & 0.839 & 0.796 & -0.092 & 0.583 & 1.099 & 0.225 & 1.422 & -0.534 & 2.144 \\
\hline
\end{tabular}


Table 9

Cont'd

\begin{tabular}{|c|c|c|c|c|c|c|c|c|c|}
\hline \multirow[t]{3}{*}{ Year } & \multirow[t]{3}{*}{ Growth Rate } & \multirow[t]{3}{*}{ St. Dev } & \multirow[t]{3}{*}{ Skewness } & \multicolumn{6}{|c|}{ Confidence Interval } \\
\hline & & & & \multicolumn{2}{|c|}{30 percent } & \multicolumn{2}{|c|}{60 percent } & \multicolumn{2}{|c|}{90 percent } \\
\hline & & & & Lower & Upper & Lower & Upper & Lower & Upper \\
\hline 2023M01 & 0.84 & 0.799 & -0.09 & 0.582 & 1.101 & 0.223 & 1.424 & -0.538 & 2.149 \\
\hline 2023M02 & 0.838 & 0.799 & -0.081 & 0.583 & 1.103 & 0.222 & 1.428 & -0.534 & 2.152 \\
\hline 2023M03 & 0.84 & 0.802 & -0.078 & 0.583 & 1.105 & 0.221 & 1.43 & -0.537 & 2.159 \\
\hline 2023M04 & 0.84 & 0.806 & -0.069 & 0.583 & 1.107 & 0.221 & 1.433 & -0.54 & 2.17 \\
\hline 2023M05 & 0.839 & 0.808 & -0.067 & 0.584 & 1.108 & 0.219 & 1.435 & -0.543 & 2.173 \\
\hline 2023M06 & 0.842 & 0.809 & -0.073 & 0.584 & 1.11 & 0.219 & 1.437 & -0.545 & 2.176 \\
\hline 2023M07 & 0.842 & 0.81 & -0.071 & 0.584 & 1.11 & 0.219 & 1.441 & -0.545 & 2.178 \\
\hline 2023M08 & 0.844 & 0.812 & -0.074 & 0.584 & 1.112 & 0.218 & 1.443 & -0.548 & 2.181 \\
\hline 2023M09 & 0.843 & 0.814 & -0.07 & 0.584 & 1.113 & 0.219 & 1.446 & -0.549 & 2.186 \\
\hline $2023 \mathrm{M} 10$ & 0.846 & 0.815 & -0.076 & 0.585 & 1.116 & 0.219 & 1.448 & -0.552 & 2.188 \\
\hline $2023 \mathrm{M} 11$ & 0.846 & 0.817 & -0.077 & 0.586 & 1.118 & 0.22 & 1.449 & -0.556 & 2.192 \\
\hline $2023 \mathrm{M} 12$ & 0.848 & 0.818 & -0.081 & 0.586 & 1.12 & 0.221 & 1.45 & -0.558 & 2.194 \\
\hline 2024M01 & 0.847 & 0.819 & -0.08 & 0.586 & 1.123 & 0.22 & 1.452 & -0.557 & 2.195 \\
\hline 2024M02 & 0.849 & 0.82 & -0.079 & 0.587 & 1.124 & 0.221 & 1.455 & -0.558 & 2.199 \\
\hline 2024M03 & 0.85 & 0.821 & -0.074 & 0.589 & 1.124 & 0.222 & 1.458 & -0.557 & 2.205 \\
\hline 2024M04 & 0.852 & 0.824 & -0.078 & 0.589 & 1.126 & 0.22 & 1.46 & -0.561 & 2.208 \\
\hline 2024M05 & 0.852 & 0.824 & -0.077 & 0.59 & 1.127 & 0.22 & 1.46 & -0.562 & 2.21 \\
\hline 2024M06 & 0.854 & 0.825 & -0.082 & 0.591 & 1.129 & 0.22 & 1.461 & -0.564 & 2.211 \\
\hline 2024M07 & 0.854 & 0.825 & -0.084 & 0.592 & 1.129 & 0.221 & 1.463 & -0.563 & 2.21 \\
\hline 2024M08 & 0.857 & 0.826 & -0.084 & 0.593 & 1.13 & 0.223 & 1.466 & -0.563 & 2.215 \\
\hline 2024M09 & 0.858 & 0.826 & -0.088 & 0.593 & 1.131 & 0.222 & 1.468 & -0.564 & 2.213 \\
\hline 2024M10 & 0.858 & 0.833 & -0.054 & 0.594 & 1.131 & 0.221 & 1.468 & -0.565 & 2.241 \\
\hline $2024 \mathrm{M} 11$ & 0.859 & 0.828 & -0.084 & 0.594 & 1.132 & 0.223 & 1.469 & -0.564 & 2.219 \\
\hline 2024M12 & 0.86 & 0.828 & -0.089 & 0.593 & 1.134 & 0.224 & 1.471 & -0.565 & 2.217 \\
\hline 2025M01 & 0.861 & 0.884 & 0.21 & 0.593 & 1.135 & 0.224 & 1.472 & -0.565 & 2.445 \\
\hline 2025M02 & 0.849 & 0.927 & 0.427 & 0.593 & 1.136 & 0.224 & 1.475 & -0.566 & 2.611 \\
\hline 2025M03 & 0.861 & 1.006 & 0.74 & 0.594 & 1.137 & 0.224 & 1.477 & -0.566 & 2.9 \\
\hline 2025M04 & 0.861 & 1.003 & 0.726 & 0.595 & 1.137 & 0.226 & 1.478 & -0.566 & 2.889 \\
\hline 2025M05 & 0.86 & 1.009 & 0.75 & 0.595 & 1.137 & 0.226 & 1.479 & -0.567 & 2.911 \\
\hline 2025M06 & 0.861 & 1.026 & 0.801 & 0.595 & 1.138 & 0.226 & 1.481 & -0.57 & 2.967 \\
\hline 2025M07 & 0.861 & 1.014 & 0.763 & 0.595 & 1.137 & 0.225 & 1.481 & -0.569 & 2.928 \\
\hline 2025M08 & 0.858 & 1.026 & 0.806 & 0.595 & 1.138 & 0.224 & 1.482 & -0.568 & 2.967 \\
\hline 2025M09 & 0.861 & 1.016 & 0.77 & 0.596 & 1.138 & 0.225 & 1.484 & -0.568 & 2.935 \\
\hline 2025M10 & 0.862 & 1.005 & 0.716 & 0.595 & 1.139 & 0.224 & 1.487 & -0.571 & 2.891 \\
\hline $2025 \mathrm{M} 11$ & 0.863 & 0.998 & 0.69 & 0.596 & 1.139 & 0.225 & 1.488 & -0.57 & 2.867 \\
\hline $2025 \mathrm{M} 12$ & 0.863 & 0.981 & 0.618 & 0.596 & 1.14 & 0.226 & 1.49 & -0.571 & 2.803 \\
\hline 2026M01 & 0.863 & 0.971 & 0.579 & 0.596 & 1.141 & 0.227 & 1.489 & -0.57 & 2.767 \\
\hline 2026M02 & 0.864 & 0.965 & 0.555 & 0.596 & 1.142 & 0.227 & 1.491 & -0.569 & 2.747 \\
\hline $2026 \mathrm{M} 03$ & 0.864 & 0.949 & 0.484 & 0.596 & 1.144 & 0.227 & 1.491 & -0.569 & 2.686 \\
\hline 2026M04 & 0.865 & 0.902 & 0.265 & 0.596 & 1.144 & 0.227 & 1.492 & -0.568 & 2.505 \\
\hline 2026M05 & 0.865 & 0.847 & -0.025 & 0.597 & 1.144 & 0.226 & 1.492 & -0.569 & 2.283 \\
\hline 2026M06 & 0.864 & 0.841 & -0.054 & 0.596 & 1.144 & 0.226 & 1.492 & -0.569 & 2.259 \\
\hline 2026M07 & 0.865 & 0.839 & -0.068 & 0.596 & 1.144 & 0.227 & 1.493 & -0.569 & 2.25 \\
\hline 2026M08 & 0.867 & 0.842 & -0.05 & 0.595 & 1.144 & 0.229 & 1.496 & -0.568 & 2.264 \\
\hline 2026M09 & 0.867 & 0.839 & -0.065 & 0.595 & 1.145 & 0.231 & 1.496 & -0.568 & 2.254 \\
\hline $2026 \mathrm{M} 10$ & 0.869 & 0.84 & -0.064 & 0.593 & 1.144 & 0.231 & 1.496 & -0.568 & 2.255 \\
\hline 2026M11 & 0.869 & 0.843 & -0.052 & 0.593 & 1.144 & 0.232 & 1.496 & -0.569 & 2.266 \\
\hline 2026M12 & 0.869 & 0.843 & -0.053 & 0.593 & 1.144 & 0.232 & 1.498 & -0.57 & 2.266 \\
\hline 2027M01 & 0.86 & 0.844 & -0.041 & 0.592 & 1.143 & 0.233 & 1.499 & -0.572 & 2.269 \\
\hline 2027M02 & 0.869 & 0.849 & -0.017 & 0.592 & 1.143 & 0.234 & 1.499 & -0.569 & 2.292 \\
\hline 2027M03 & 0.867 & 0.847 & -0.031 & 0.591 & 1.143 & 0.235 & 1.499 & -0.571 & 2.282 \\
\hline 2027M04 & 0.866 & 0.845 & -0.044 & 0.592 & 1.142 & 0.235 & 1.497 & -0.572 & 2.272 \\
\hline 2027M05 & 0.868 & 0.847 & -0.042 & 0.593 & 1.142 & 0.235 & 1.499 & -0.575 & 2.279 \\
\hline 2027M06 & 0.865 & 0.848 & -0.035 & 0.593 & 1.142 & 0.235 & 1.499 & -0.577 & 2.282 \\
\hline $2027 \mathrm{M} 07$ & 0.867 & 0.846 & -0.051 & 0.594 & 1.141 & 0.236 & 1.499 & -0.578 & 2.274 \\
\hline 2027M08 & 0.868 & 0.845 & -0.061 & 0.592 & 1.141 & 0.234 & 1.498 & -0.578 & 2.266 \\
\hline 2027M09 & 0.868 & 0.845 & -0.065 & 0.591 & 1.14 & 0.234 & 1.499 & -0.58 & 2.264 \\
\hline 2027M10 & 0.863 & 0.845 & -0.057 & 0.591 & 1.141 & 0.234 & 1.499 & -0.579 & 2.265 \\
\hline $2027 \mathrm{M} 11$ & 0.866 & 0.846 & -0.061 & 0.59 & 1.141 & 0.235 & 1.5 & -0.58 & 2.267 \\
\hline
\end{tabular}


Table 9

Cont'd

\begin{tabular}{cccccccccc}
\hline Year & Growth Rate & St. Dev & Skewness & \multicolumn{7}{c}{ Confidence Interval } \\
\hline & & & & \multicolumn{2}{c}{ 30 percent } & 60 percent & 90 percent \\
\cline { 5 - 9 } & & & & Lower & Upper & Lower & Upper & Lower & Upper \\
\hline $2027 \mathrm{M} 12$ & 0.868 & 0.846 & -0.059 & 0.59 & 1.14 & 0.235 & 1.5 & -0.58 & 2.27 \\
2028M01 & 0.867 & 0.846 & -0.06 & 0.589 & 1.139 & 0.234 & 1.5 & -0.581 & 2.268 \\
2028M02 & 0.867 & 0.846 & -0.067 & 0.589 & 1.139 & 0.233 & 1.501 & -0.582 & 2.264 \\
2028M03 & 0.868 & 0.846 & -0.062 & 0.588 & 1.14 & 0.232 & 1.501 & -0.581 & 2.266 \\
2028M04 & 0.868 & 0.847 & -0.058 & 0.588 & 1.14 & 0.231 & 1.499 & -0.581 & 2.27 \\
2028M05 & 0.861 & 0.847 & -0.047 & 0.588 & 1.14 & 0.231 & 1.5 & -0.58 & 2.27 \\
2028M06 & 0.869 & 0.847 & -0.052 & 0.589 & 1.141 & 0.23 & 1.5 & -0.578 & 2.271 \\
2028M07 & 0.868 & 0.847 & -0.046 & 0.587 & 1.14 & 0.229 & 1.5 & -0.576 & 2.273 \\
2028M08 & 0.868 & 0.848 & -0.049 & 0.587 & 1.14 & 0.23 & 1.499 & -0.58 & 2.274 \\
2028M09 & 0.868 & 0.848 & -0.042 & 0.588 & 1.14 & 0.228 & 1.498 & -0.577 & 2.276 \\
2028M10 & 0.866 & 0.847 & -0.037 & 0.588 & 1.14 & 0.228 & 1.498 & -0.575 & 2.277 \\
2028M11 & 0.866 & 0.848 & -0.033 & 0.587 & 1.139 & 0.228 & 1.498 & -0.575 & 2.279 \\
2028M12 & 0.864 & 0.847 & -0.034 & 0.587 & 1.139 & 0.228 & 1.498 & -0.576 & 2.276 \\
\hline
\end{tabular}

Source: Author's estimation 
Table 10

Result of Fan Chart of Worker's Remittances Growth (Monthly Data)

\begin{tabular}{|c|c|c|c|c|c|c|c|c|c|}
\hline \multirow[t]{3}{*}{ Year } & \multirow[t]{3}{*}{ Growth Rate } & \multirow[t]{3}{*}{ St. Dev } & \multirow[t]{3}{*}{ Skewness } & \multicolumn{6}{|c|}{ Confidence Interval } \\
\hline & & & & \multicolumn{2}{|c|}{30 percent } & \multicolumn{2}{|c|}{60 percent } & \multicolumn{2}{|c|}{90 percent } \\
\hline & & & & Lower & Upper & Lower & Upper & Lower & Upper \\
\hline 2018M02 & 6.736 & 0.035 & 0.158 & 6.728 & 6.744 & 6.718 & 6.756 & 6.676 & 6.801 \\
\hline 2018M03 & 6.747 & 0.207 & -2.449 & 6.733 & 6.762 & 6.715 & 6.783 & 6.201 & 6.885 \\
\hline 2018M04 & 6.756 & 0.26 & -2.227 & 6.733 & 6.778 & 6.705 & 6.811 & 6.089 & 6.973 \\
\hline 2018M05 & 6.762 & 0.315 & -2.015 & 6.73 & 6.793 & 6.689 & 6.839 & 5.976 & 7.066 \\
\hline 2018M06 & 6.765 & 0.366 & -1.809 & 6.723 & 6.807 & 6.667 & 6.867 & 5.876 & 7.159 \\
\hline 2018M07 & 6.766 & 0.435 & -1.687 & 6.712 & 6.819 & 6.639 & 6.897 & 5.728 & 7.259 \\
\hline 2018M08 & 6.765 & 0.488 & -1.498 & 6.698 & 6.83 & 6.607 & 6.928 & 5.63 & 7.36 \\
\hline 2018M09 & 6.763 & 0.572 & -1.483 & 6.682 & 6.84 & 6.57 & 6.959 & 5.435 & 7.46 \\
\hline $2018 \mathrm{M} 10$ & 6.757 & 0.62 & -1.338 & 6.662 & 6.849 & 6.529 & 6.989 & 5.349 & 7.55 \\
\hline 2018M11 & 6.75 & 0.614 & -0.903 & 6.641 & 6.857 & 6.484 & 7.02 & 5.447 & 7.641 \\
\hline $2018 \mathrm{M} 12$ & 6.742 & 0.588 & -0.239 & 6.617 & 6.864 & 6.438 & 7.05 & 5.641 & 7.736 \\
\hline 2019M01 & 6.733 & 0.641 & -0.213 & 6.592 & 6.87 & 6.388 & 7.08 & 5.54 & 7.82 \\
\hline 2019M02 & 6.722 & 0.697 & -0.194 & 6.565 & 6.875 & 6.337 & 7.111 & 5.435 & 7.904 \\
\hline 2019M03 & 6.723 & 0.753 & -0.206 & 6.536 & 6.879 & 6.283 & 7.14 & 5.323 & 7.985 \\
\hline 2019M04 & 6.703 & 0.81 & -0.196 & 6.504 & 6.883 & 6.227 & 7.17 & 5.21 & 8.062 \\
\hline 2019M05 & 6.686 & 0.864 & -0.176 & 6.474 & 6.888 & 6.17 & 7.197 & 5.106 & 8.14 \\
\hline 2019M06 & 6.671 & 0.915 & -0.153 & 6.442 & 6.89 & 6.114 & 7.224 & 5.01 & 8.216 \\
\hline 2019M07 & 6.655 & 0.966 & -0.136 & 6.409 & 6.892 & 6.058 & 7.248 & 4.911 & 8.289 \\
\hline 2019M08 & 6.64 & 1.017 & -0.118 & 6.374 & 6.895 & 5.998 & 7.274 & 4.816 & 8.36 \\
\hline 2019M09 & 6.624 & 1.068 & -0.091 & 6.339 & 6.895 & 5.937 & 7.297 & 4.723 & 8.438 \\
\hline 2019M10 & 6.612 & 1.115 & -0.074 & 6.305 & 6.896 & 5.88 & 7.322 & 4.636 & 8.507 \\
\hline 2019M11 & 6.591 & 1.163 & -0.053 & 6.269 & 6.895 & 5.82 & 7.341 & 4.546 & 8.574 \\
\hline 2019M12 & 6.573 & 1.21 & -0.031 & 6.234 & 6.893 & 5.76 & 7.362 & 4.461 & 8.643 \\
\hline 2020M01 & 6.557 & 1.255 & -0.011 & 6.197 & 6.892 & 5.701 & 7.382 & 4.379 & 8.708 \\
\hline 2020M02 & 6.548 & 1.298 & -0.013 & 6.162 & 6.888 & 5.647 & 7.401 & 4.293 & 8.762 \\
\hline 2020M03 & 6.521 & 1.34 & -0.003 & 6.128 & 6.886 & 5.591 & 7.417 & 4.207 & 8.815 \\
\hline 2020M04 & 6.505 & 1.379 & 0.008 & 6.09 & 6.885 & 5.536 & 7.432 & 4.133 & 8.865 \\
\hline 2020M05 & 6.487 & 1.418 & 0.023 & 6.054 & 6.884 & 5.479 & 7.45 & 4.061 & 8.918 \\
\hline 2020M06 & 6.47 & 1.457 & 0.033 & 6.019 & 6.88 & 5.426 & 7.465 & 3.989 & 8.968 \\
\hline 2020M07 & 6.454 & 1.491 & 0.038 & 5.985 & 6.876 & 5.374 & 7.477 & 3.918 & 9.009 \\
\hline 2020M08 & 6.434 & 1.527 & 0.049 & 5.951 & 6.871 & 5.322 & 7.488 & 3.849 & 9.056 \\
\hline 2020M09 & 6.415 & 1.561 & 0.057 & 5.919 & 6.867 & 5.269 & 7.5 & 3.784 & 9.096 \\
\hline $2020 \mathrm{M} 10$ & 6.395 & 1.592 & 0.066 & 5.886 & 6.858 & 5.222 & 7.51 & 3.721 & 9.133 \\
\hline 2020M11 & 6.377 & 1.625 & 0.082 & 5.855 & 6.854 & 5.177 & 7.522 & 3.662 & 9.181 \\
\hline $2020 \mathrm{M} 12$ & 6.359 & 1.656 & 0.084 & 5.824 & 6.851 & 5.131 & 7.53 & 3.597 & 9.215 \\
\hline 2021M01 & 6.338 & 1.685 & 0.092 & 5.793 & 6.845 & 5.082 & 7.541 & 3.539 & 9.248 \\
\hline 2021M02 & 6.32 & 1.717 & 0.097 & 5.762 & 6.839 & 5.039 & 7.552 & 3.476 & 9.287 \\
\hline 2021M03 & 6.301 & 1.743 & 0.105 & 5.731 & 6.835 & 4.999 & 7.559 & 3.423 & 9.319 \\
\hline 2021M04 & 6.28 & 1.769 & 0.101 & 5.704 & 6.827 & 4.954 & 7.569 & 3.363 & 9.337 \\
\hline 2021M05 & 6.262 & 1.796 & 0.099 & 5.674 & 6.821 & 4.913 & 7.574 & 3.302 & 9.363 \\
\hline 2021M06 & 6.217 & 1.821 & 0.115 & 5.645 & 6.816 & 4.875 & 7.582 & 3.246 & 9.387 \\
\hline 2021M07 & 6.225 & 1.844 & 0.098 & 5.617 & 6.811 & 4.835 & 7.588 & 3.193 & 9.405 \\
\hline 2021M08 & 6.208 & 1.867 & 0.104 & 5.587 & 6.803 & 4.798 & 7.592 & 3.146 & 9.429 \\
\hline 2021M09 & 6.196 & 1.889 & 0.105 & 5.563 & 6.797 & 4.761 & 7.598 & 3.1 & 9.452 \\
\hline $2021 \mathrm{M} 10$ & 6.176 & 1.911 & 0.11 & 5.539 & 6.791 & 4.725 & 7.602 & 3.054 & 9.475 \\
\hline $2021 \mathrm{M} 11$ & 6.166 & 1.932 & 0.113 & 5.513 & 6.782 & 4.689 & 7.606 & 3.01 & 9.497 \\
\hline $2021 \mathrm{M} 12$ & 6.148 & 1.952 & 0.123 & 5.489 & 6.776 & 4.656 & 7.609 & 2.972 & 9.524 \\
\hline 2022M01 & 6.104 & 1.972 & 0.146 & 5.465 & 6.768 & 4.623 & 7.614 & 2.934 & 9.549 \\
\hline 2022M02 & 6.118 & 1.991 & 0.136 & 5.44 & 6.756 & 4.594 & 7.619 & 2.892 & 9.569 \\
\hline 2022M03 & 6.127 & 2.01 & 0.121 & 5.419 & 6.749 & 4.563 & 7.623 & 2.846 & 9.583 \\
\hline 2022M04 & 6.09 & 2.026 & 0.131 & 5.399 & 6.743 & 4.536 & 7.627 & 2.807 & 9.596 \\
\hline 2022M05 & 6.073 & 2.043 & 0.133 & 5.378 & 6.736 & 4.506 & 7.629 & 2.769 & 9.608 \\
\hline 2022M06 & 6.061 & 2.059 & 0.134 & 5.357 & 6.728 & 4.481 & 7.631 & 2.732 & 9.624 \\
\hline 2022M07 & 6.047 & 2.072 & 0.137 & 5.338 & 6.718 & 4.453 & 7.632 & 2.702 & 9.634 \\
\hline 2022M08 & 6.033 & 2.09 & 0.143 & 5.32 & 6.71 & 4.427 & 7.637 & 2.667 & 9.657 \\
\hline 2022M09 & 6.019 & 2.104 & 0.143 & 5.298 & 6.699 & 4.402 & 7.641 & 2.633 & 9.665 \\
\hline $2022 \mathrm{M} 10$ & 6.006 & 2.116 & 0.145 & 5.282 & 6.689 & 4.377 & 7.642 & 2.603 & 9.675 \\
\hline 2022M11 & 5.992 & 2.13 & 0.142 & 5.263 & 6.68 & 4.356 & 7.643 & 2.565 & 9.681 \\
\hline 2022M12 & 5.979 & 2.145 & 0.144 & 5.242 & 6.672 & 4.332 & 7.642 & 2.53 & 9.696 \\
\hline
\end{tabular}


Table 10

Cont'd

\begin{tabular}{|c|c|c|c|c|c|c|c|c|c|}
\hline \multirow[t]{3}{*}{ Year } & \multirow[t]{3}{*}{ Growth Rate } & \multirow[t]{3}{*}{ St. Dev } & \multirow[t]{3}{*}{ Skewness } & \multicolumn{6}{|c|}{ Confidence Interval } \\
\hline & & & & \multicolumn{2}{|c|}{30 percent } & \multicolumn{2}{|c|}{60 percent } & \multicolumn{2}{|c|}{90 percent } \\
\hline & & & & Lower & Upper & Lower & Upper & Lower & Upper \\
\hline 2023M01 & 5.97 & 2.157 & 0.142 & 5.225 & 6.666 & 4.305 & 7.643 & 2.5 & 9.701 \\
\hline 2023M02 & 5.959 & 2.171 & 0.143 & 5.209 & 6.66 & 4.284 & 7.643 & 2.468 & 9.717 \\
\hline 2023M03 & 5.942 & 2.185 & 0.143 & 5.192 & 6.653 & 4.268 & 7.645 & 2.431 & 9.727 \\
\hline 2023M04 & 5.934 & 2.199 & 0.153 & 5.175 & 6.647 & 4.245 & 7.647 & 2.411 & 9.751 \\
\hline 2023M05 & 5.922 & 2.211 & 0.15 & 5.16 & 6.641 & 4.226 & 7.646 & 2.377 & 9.758 \\
\hline 2023M06 & 5.911 & 2.22 & 0.15 & 5.148 & 6.635 & 4.21 & 7.645 & 2.353 & 9.764 \\
\hline 2023M07 & 5.901 & 2.232 & 0.155 & 5.132 & 6.63 & 4.194 & 7.646 & 2.329 & 9.78 \\
\hline 2023M08 & 5.888 & 2.244 & 0.16 & 5.117 & 6.625 & 4.176 & 7.642 & 2.304 & 9.794 \\
\hline 2023M09 & 5.879 & 2.253 & 0.166 & 5.101 & 6.616 & 4.16 & 7.643 & 2.285 & 9.806 \\
\hline $2023 \mathrm{M} 10$ & 5.871 & 2.264 & 0.172 & 5.085 & 6.609 & 4.144 & 7.641 & 2.263 & 9.821 \\
\hline 2023M11 & 5.86 & 2.272 & 0.174 & 5.07 & 6.601 & 4.127 & 7.64 & 2.243 & 9.826 \\
\hline $2023 \mathrm{M} 12$ & 5.852 & 2.283 & 0.177 & 5.059 & 6.593 & 4.115 & 7.644 & 2.221 & 9.841 \\
\hline 2024M01 & 5.841 & 2.291 & 0.172 & 5.047 & 6.589 & 4.101 & 7.644 & 2.194 & 9.84 \\
\hline 2024M02 & 5.83 & 2.298 & 0.172 & 5.035 & 6.582 & 4.089 & 7.642 & 2.174 & 9.843 \\
\hline 2024M03 & 5.823 & 2.308 & 0.174 & 5.024 & 6.576 & 4.08 & 7.642 & 2.149 & 9.856 \\
\hline 2024M04 & 5.809 & 2.319 & 0.178 & 5.012 & 6.57 & 4.068 & 7.643 & 2.125 & 9.869 \\
\hline 2024M05 & 5.805 & 2.328 & 0.176 & 4.998 & 6.562 & 4.053 & 7.642 & 2.102 & 9.876 \\
\hline 2024M06 & 5.797 & 2.339 & 0.179 & 4.991 & 6.56 & 4.043 & 7.644 & 2.079 & 9.893 \\
\hline 2024M07 & 5.791 & 2.347 & 0.183 & 4.981 & 6.556 & 4.033 & 7.646 & 2.065 & 9.906 \\
\hline 2024M08 & 5.78 & 2.354 & 0.186 & 4.972 & 6.549 & 4.019 & 7.644 & 2.049 & 9.91 \\
\hline 2024M09 & 5.774 & 2.361 & 0.188 & 4.963 & 6.542 & 4.006 & 7.643 & 2.031 & 9.919 \\
\hline 2024M10 & 5.765 & 2.369 & 0.194 & 4.953 & 6.536 & 3.995 & 7.639 & 2.017 & 9.931 \\
\hline $2024 \mathrm{M} 11$ & 5.759 & 2.374 & 0.198 & 4.943 & 6.529 & 3.983 & 7.643 & 2.007 & 9.937 \\
\hline 2024M12 & 5.754 & 2.377 & 0.196 & 4.937 & 6.524 & 3.97 & 7.637 & 1.995 & 9.934 \\
\hline 2025M01 & 5.751 & 2.384 & 0.198 & 4.929 & 6.515 & 3.962 & 7.634 & 1.981 & 9.943 \\
\hline 2025M02 & 5.742 & 2.391 & 0.2 & 4.922 & 6.514 & 3.952 & 7.637 & 1.964 & 9.952 \\
\hline 2025M03 & 5.748 & 2.396 & 0.196 & 4.912 & 6.514 & 3.945 & 7.635 & 1.954 & 9.957 \\
\hline 2025M04 & 5.73 & 2.403 & 0.209 & 4.901 & 6.509 & 3.932 & 7.634 & 1.944 & 9.97 \\
\hline 2025M05 & 5.723 & 2.411 & 0.211 & 4.892 & 6.504 & 3.918 & 7.63 & 1.928 & 9.979 \\
\hline 2025M06 & 5.717 & 2.415 & 0.21 & 4.887 & 6.502 & 3.912 & 7.629 & 1.914 & 9.981 \\
\hline $2025 \mathrm{M} 07$ & 5.713 & 2.42 & 0.216 & 4.878 & 6.499 & 3.908 & 7.629 & 1.908 & 9.991 \\
\hline 2025M08 & 5.708 & 2.426 & 0.22 & 4.873 & 6.496 & 3.901 & 7.628 & 1.897 & 10.003 \\
\hline 2025M09 & 5.701 & 2.429 & 0.218 & 4.868 & 6.496 & 3.895 & 7.628 & 1.886 & 10.001 \\
\hline 2025M10 & 5.706 & 2.436 & 0.218 & 4.863 & 6.49 & 3.888 & 7.624 & 1.872 & 10.015 \\
\hline $2025 \mathrm{M} 11$ & 5.691 & 2.44 & 0.225 & 4.857 & 6.488 & 3.882 & 7.621 & 1.864 & 10.022 \\
\hline $2025 \mathrm{M} 12$ & 5.686 & 2.444 & 0.223 & 4.852 & 6.488 & 3.874 & 7.618 & 1.851 & 10.022 \\
\hline 2026M01 & 5.681 & 2.45 & 0.224 & 4.846 & 6.481 & 3.865 & 7.615 & 1.836 & 10.028 \\
\hline 2026M02 & 5.676 & 2.455 & 0.222 & 4.841 & 6.478 & 3.857 & 7.619 & 1.824 & 10.029 \\
\hline $2026 \mathrm{M} 03$ & 5.67 & 2.459 & 0.222 & 4.833 & 6.475 & 3.854 & 7.617 & 1.809 & 10.034 \\
\hline 2026M04 & 5.658 & 2.467 & 0.227 & 4.827 & 6.473 & 3.848 & 7.617 & 1.795 & 10.046 \\
\hline 2026M05 & 5.662 & 2.472 & 0.224 & 4.825 & 6.472 & 3.841 & 7.617 & 1.784 & 10.052 \\
\hline 2026M06 & 5.653 & 2.475 & 0.225 & 4.821 & 6.469 & 3.837 & 7.617 & 1.775 & 10.053 \\
\hline 2026M07 & 5.654 & 2.478 & 0.225 & 4.817 & 6.467 & 3.83 & 7.618 & 1.769 & 10.057 \\
\hline 2026M08 & 5.638 & 2.482 & 0.234 & 4.814 & 6.464 & 3.827 & 7.617 & 1.763 & 10.066 \\
\hline 2026M09 & 5.638 & 2.485 & 0.236 & 4.809 & 6.457 & 3.819 & 7.616 & 1.758 & 10.07 \\
\hline $2026 \mathrm{M} 10$ & 5.636 & 2.486 & 0.232 & 4.802 & 6.455 & 3.815 & 7.617 & 1.751 & 10.064 \\
\hline 2026M11 & 5.635 & 2.489 & 0.228 & 4.799 & 6.452 & 3.809 & 7.616 & 1.739 & 10.063 \\
\hline 2026M12 & 5.632 & 2.494 & 0.232 & 4.796 & 6.452 & 3.805 & 7.617 & 1.732 & 10.076 \\
\hline 2027M01 & 5.627 & 2.501 & 0.233 & 4.789 & 6.45 & 3.798 & 7.618 & 1.717 & 10.086 \\
\hline 2027M02 & 5.624 & 2.505 & 0.235 & 4.784 & 6.451 & 3.789 & 7.617 & 1.712 & 10.091 \\
\hline 2027M03 & 5.622 & 2.509 & 0.237 & 4.784 & 6.449 & 3.783 & 7.615 & 1.705 & 10.099 \\
\hline 2027M04 & 5.616 & 2.515 & 0.238 & 4.778 & 6.447 & 3.776 & 7.616 & 1.692 & 10.105 \\
\hline 2027M05 & 5.616 & 2.515 & 0.232 & 4.774 & 6.443 & 3.77 & 7.615 & 1.683 & 10.097 \\
\hline 2027M06 & 5.61 & 2.522 & 0.237 & 4.767 & 6.44 & 3.766 & 7.616 & 1.671 & 10.11 \\
\hline 2027M07 & 5.615 & 2.525 & 0.233 & 4.765 & 6.438 & 3.76 & 7.61 & 1.662 & 10.112 \\
\hline 2027M08 & 5.597 & 2.529 & 0.243 & 4.76 & 6.437 & 3.756 & 7.611 & 1.659 & 10.122 \\
\hline 2027M09 & 5.61 & 2.536 & 0.245 & 4.756 & 6.435 & 3.753 & 7.613 & 1.652 & 10.141 \\
\hline 2027M10 & 5.6 & 2.62 & 0.38 & 4.753 & 6.434 & 3.748 & 7.608 & 1.643 & 10.464 \\
\hline $2027 \mathrm{M} 11$ & 5.597 & 2.65 & 0.42 & 4.747 & 6.43 & 3.745 & 7.605 & 1.631 & 10.568 \\
\hline
\end{tabular}


Table 10

Cont'd

\begin{tabular}{cccccccccc}
\hline Year & Growth Rate & St. Dev & Skewness & \multicolumn{7}{c}{ Confidence Interval } \\
\hline & & & & \multicolumn{2}{c}{ 30 percent } & 60 percent & 90 percent \\
\cline { 5 - 9 } & & & & Lower & Upper & Lower & Upper & Lower & Upper \\
\hline $2027 \mathrm{M} 12$ & 5.592 & 2.606 & 0.348 & 4.743 & 6.427 & 3.74 & 7.606 & 1.626 & 10.389 \\
$2028 \mathrm{M} 01$ & 5.584 & 2.72 & 0.523 & 4.738 & 6.426 & 3.741 & 7.606 & 1.62 & 10.822 \\
$2028 \mathrm{M} 02$ & 5.585 & 2.821 & 0.662 & 4.734 & 6.424 & 3.735 & 7.601 & 1.615 & 11.192 \\
$2028 \mathrm{M} 03$ & 5.581 & 2.86 & 0.709 & 4.733 & 6.421 & 3.73 & 7.602 & 1.607 & 11.325 \\
$2028 \mathrm{M} 04$ & 5.603 & 2.874 & 0.716 & 4.731 & 6.422 & 3.726 & 7.603 & 1.602 & 11.372 \\
$2028 \mathrm{M} 05$ & 5.534 & 2.953 & 0.829 & 4.73 & 6.422 & 3.721 & 7.603 & 1.594 & 11.641 \\
$2028 \mathrm{M} 06$ & 5.603 & 2.963 & 0.82 & 4.722 & 6.42 & 3.72 & 7.598 & 1.587 & 11.679 \\
$2028 \mathrm{M} 07$ & 5.567 & 3.01 & 0.878 & 4.719 & 6.419 & 3.717 & 7.597 & 1.575 & 11.831 \\
$2028 \mathrm{M} 08$ & 5.565 & 3.024 & 0.887 & 4.715 & 6.418 & 3.715 & 7.596 & 1.563 & 11.872 \\
$2028 \mathrm{M} 09$ & 5.563 & 3.042 & 0.908 & 4.716 & 6.416 & 3.711 & 7.596 & 1.563 & 11.934 \\
$2028 \mathrm{M} 10$ & 5.561 & 3.061 & 0.927 & 4.711 & 6.411 & 3.702 & 7.598 & 1.557 & 11.993 \\
$2028 \mathrm{M} 11$ & 5.561 & 3.099 & 0.967 & 4.709 & 6.411 & 3.695 & 7.593 & 1.554 & 12.122 \\
$2028 \mathrm{M} 12$ & 5.551 & 3.107 & 0.976 & 4.707 & 6.41 & 3.689 & 7.592 & 1.551 & 12.144 \\
\hline
\end{tabular}

Source: Author's estimation 


\section{References}

Ahmad, A., Iqbal, N., \& Siddiqui, R. (2018). Determinants of housing demand in urban areas of Pakistan: Evidence from the PSLM. The Pakistan Development Review, $57(1), 1-25$.

Annett, A. (2005). House prices and monetary policy in the euro area. Chapter III in Euro area policies: selected issues, IMF Country Report, 5, 266.

Blix, M., \& Sellin, P. (1998). Uncertainty bands for inflation forecasts (Tech. Rep.). Sveriges Riksbank Working Paper Series.

Brown, J. P., Song, H., \& McGillivray, A. (1997). Forecasting uk house prices: A time varying coefficient approach. Economic Modelling, 14(4), 529-548.

Camilleri, G., \& Vella, K. J. (2015). Interpolating forecast errors for assessing uncertainty in macroeconomic forecasts: An analysis for Malta.

Chiu, R. L. (2006). Globalization and localization: Economic performance and the housing markets of the Asian Tigers since the financial crisis. Housing Finance International, $20(3), 12$.

Chow, G. C., \& Lin, A.-l. (1971). Best linear unbiased interpolation, distribution, and extrapolation of time series by related series. The Review of Economics and Statistics, $372-375$.

Clapp, J., \& Giaccotto, C. (2002). Evaluating house price forecasts. Journal of Real Estate Research, 24(1), 1-26.

Crawford, G. W., \& Fratantoni, M. C. (2003). Assessing the forecasting performance of regime-switching, ARIMA and GARCH models of house prices. Real Estate Economics, 31(2), 223-243.

Feng, L., Lin, C.-Y., \& Wang, C. (2017). Do capital flows matter to stock and house prices? Evidence from China. Emerging Markets Finance and Trade, 53(10), 2215-2232.

Fung, K. K., \& Forrest, R. (2002). Institutional mediation, the Hong Kong residential housing market and the Asian financial crisis. Housing Studies, 17(2), 189-207.

Geltner, D., MacGregor, B. D., \& Schwann, G. M. (2003). Appraisal smoothing and price discovery in real estate markets. Urban Studies, 40(5-6), 1047-1064.

Gholipour, H. F. (2013). The effect of foreign real estate investments on house prices: Evidence from emerging economies. International Journal of Strategic Property Management, 17(1), 32-43.

Gholipour, H. F., Al-Mulali, U., \& Mohammed, A. H. (2014). Foreign investments in real estate, economic growth and property prices: Evidence from oecd countries. Journal of Economic Policy Reform, 17(1), 33-45.

Giaccotto, C., \& Clapp, J. (1992). Appraisal-based real estate returns under alternative market regimes. Real Estate Economics, 20(1), 1-24.

Guirguis, H. S., Giannikos, C. I., \& Anderson, R. I. (2005). The us housing market: Asset pricing forecasts using time varying coefficients. The Journal of Real Estate Finance and Economics, 30(1), 33-53.

Himmelberg, C., Mayer, C., \& Sinai, T. (2005). Assessing high house prices: Bubbles, fundamentals and misperceptions. Journal of Economic Perspectives, 19(4), 67-92. 
Hui, E. C., \& Chan, K. K. K. (2014). Foreign direct investment in China's real estate market. Habitat International, 43, 231-239.

Iacoviello, M. (2002). House prices and business cycles in Europe: A VAR analysis. Working Papers in Economics, 81.

Jawaid, S. T., Waheed, A., et al. (2017). Uncertainty and risk analysis of Pakistan's regional trade: Fan chart approach. Journal of Management Sciences, 4(1), 55-81.

Kannan, P., \& Elekdag, S. A. (2009). Incorporating market information into the construction of the fan chart. IMF Working Papers, 1-21.

Kaulihowa, T., \& Kamati, K. (2019). Determinants of house price volatility in Namibia. International Journal of Housing Markets and Analysis, 12(4), 807-823.

Kishor, N. K., \& Marfatia, H. A. (2018). Forecasting house prices in oecd economies. Journal of Forecasting, 37(2), 170-190.

Leamer, E. E. (2007). Housing is the business cycle (Tech. Rep.). National Bureau of Economic Research, w- 13428.

Mahalik, M. K., \& Mallick, H. (2016). Are house prices guided by fundamentals or speculative factors? An empirical inquiry for India. International Journal of Economic Policy in Emerging Economies, 9(1), 47-64.

Malik, S., Roosli, R., \& Tariq, F. (2020). Investigation of informal housing challenges and issues: Experiences from slum and squatter of Lahore. Journal of Housing and the Built Environment, 35(1), 143-170.

Malpezzi, S. (1999). A simple error correction model of house prices. Journal of Housing Economics, 8(1), 27-62.

McCarthy, J., \& Peach, R. W. (2004). Are home prices the next bubble? Economic Policy Review, $10(3)$.

Meen, G. (2002). The time-series behavior of house prices: a transatlantic divide? Journal of Housing Economics, 11(1), 1-23.

Mohan, S., Hutson, A., MacDonald, I., \& Lin, C. C. (2019). Impact of macroeconomic indicators on housing prices. International Journal of Housing Markets and Analysis, 12(6), 1055-1071.

Obeng-Odoom, F. (2010). Urban real estate in ghana: A study of housing-related remittances from Australia. Housing Studies, 25(3), 357-373.

Poon, J. (2017). Foreign direct investment in the UK real estate market. Pacific Rim Property Research Journal, 23(3), 249-266.

Renaud, B., Zhang, M., \& Koeberle, S. (2001). Real estate and the Asian crisis: Lessons of the Thailand experience. In A global perspective on real estate cycles (pp. 25-61). Springer.

Yu, H. (2011). Uncertainty and risk analysis of the Langrun Chinese GDP Forecast: Fan charts revisited. China Economic Journal, 4 (2-3), 81-104. 